\title{
Protein Aggregation Landscape in Neurodegenerative Diseases: Clinical Relevance and Future Applications
}

\author{
Niccolò Candelise ${ }^{1,2, *}$, Silvia Scaricamazza ${ }^{1}$, Illari Salvatori ${ }^{1,3}$, Alberto Ferri ${ }^{1,2}$, Cristiana Valle ${ }^{1,2}$, \\ Valeria Manganelli ${ }^{3}$, Tina Garofalo ${ }^{3}{ }^{\mathbb{D}}{ }$, Maurizio Sorice $^{3}$ and Roberta Misasi ${ }^{3}$ \\ 1 Fondazione Santa Lucia IRCCS, c/o CERC, 00143 Rome, Italy; silviascaricamazza@gmail.com (S.S.); \\ illarisalvatori@libero.it (I.S.); alberto.ferri@cnr.it (A.F.); c.valle@hsantalucia.it (C.V.) \\ 2 Institute of Translational Pharmacology, National Research Council, 00133 Rome, Italy \\ 3 Department of Experimental Medicine, University of Rome "La Sapienza", 00161 Rome, Italy; \\ valeria.manganelli@uniroma1.it (V.M.); tina.garofalo@uniroma1.it (T.G.); maurizio.sorice@uniroma1.it (M.S.); \\ roberta.misasi@uniroma1.it (R.M.) \\ * Correspondence: niccolo.candelise@gmail.com; Tel.: +39-338-891-2668
}

\section{check for}

updates

Citation: Candelise, N.;

Scaricamazza, S.; Salvatori, I.; Ferri,

A.; Valle, C.; Manganelli, V.; Garofalo,

T.; Sorice, M.; Misasi, R. Protein

Aggregation Landscape in

Neurodegenerative Diseases: Clinical Relevance and Future Applications.

Int. J. Mol. Sci. 2021, 22, 6016.

https://doi.org/10.3390/

ijms22116016

Academic Editor: José Luis Zugaza

Received: 9 May 2021

Accepted: 29 May 2021

Published: 2 June 2021

Publisher's Note: MDPI stays neutral with regard to jurisdictional claims in published maps and institutional affiliations.

Copyright: (c) 2021 by the authors. Licensee MDPI, Basel, Switzerland. This article is an open access article distributed under the terms and conditions of the Creative Commons Attribution (CC BY) license (https:/ / creativecommons.org/licenses/by/ $4.0 /)$.

\begin{abstract}
Intrinsic disorder is a natural feature of polypeptide chains, resulting in the lack of a defined three-dimensional structure. Conformational changes in intrinsically disordered regions of a protein lead to unstable $\beta$-sheet enriched intermediates, which are stabilized by intermolecular interactions with other $\beta$-sheet enriched molecules, producing stable proteinaceous aggregates. Upon misfolding, several pathways may be undertaken depending on the composition of the amino acidic string and the surrounding environment, leading to different structures. Accumulating evidence is suggesting that the conformational state of a protein may initiate signalling pathways involved both in pathology and physiology. In this review, we will summarize the heterogeneity of structures that are produced from intrinsically disordered protein domains and highlight the routes that lead to the formation of physiological liquid droplets as well as pathogenic aggregates. The most common proteins found in aggregates in neurodegenerative diseases and their structural variability will be addressed. We will further evaluate the clinical relevance and future applications of the study of the structural heterogeneity of protein aggregates, which may aid the understanding of the phenotypic diversity observed in neurodegenerative disorders.
\end{abstract}

Keywords: intrinsic disorder; phase separation; protein aggregation; neurodegenerative disease; prion protein; alpha synuclein; TDP-43; tau; amyloid beta

\section{Introduction}

The correct function of living organisms depends on the concerted effort of a network of thousands of proteins [1-3], which are required to assume a defined structure to exert their function. Protein folding is a tightly regulated process that relies on the primary sequence of the protein. The folding depends on the energetic landscape, as thermodynamic constrictions force a protein to assume the conformation that minimizes the free energy of the system, and on the activity of chaperones helping the protein to reach its functional structure. However, intrinsically disordered regions (IDRs), found in most eukaryotic proteins [4-6], appear to show no preference for chaperone binding [7]. Thus, proteins mostly or entirely composed of IDRs, defined as intrinsically disordered proteins (IDPs), may escape the classical folding pathway and maintain a metastable and plastic state. A subset of IDRs termed low complexity domains (LCDs), found in up to $1.2 \%$ of the protein-coding human genes [8], is gaining attention due to its presence in aggregated state in most neurodegenerative disorders. Mild conformational changes in LCDs may lead to an unstable $\beta$-sheet enriched intermediate, which is further stabilized by intermolecular interactions with other $\beta$-sheet enriched molecules, thereby producing the stable proteinaceous aggregate. This mechanism may be viewed as an unorthodox signalling pathway in 
which conformational information, rather than addition or remotion of functional groups, mediates the cascade of events leading both to physiological and pathological outcomes. Furthermore, neurons do not have the ability to remove or dilute toxic molecules by mitotic division as they are terminal cells; therefore, they are very sensitive to misfolded proteins, increasingly with aging.

In this review, we will first recapitulate how intrinsic disorder determines the formation of a variety of structures and produces different states of the matter, owning both physiological and pathological features. Next, we will provide evidence of structural variability observed in the proteins most commonly associated with neurodegeneration, specifically the prion protein $(\operatorname{PrP})$, amyloid $\beta$-peptides $(\mathrm{A} \beta)$, tau, $\alpha$-synuclein and TAR DNA binding protein 43 (TDP-43). As a caveat, we will focus on the wild-type sequence of these proteins, as most neurodegenerative diseases are sporadic in nature [9]. Besides, most mutations associated with neurodegenerative diseases map on the LCDs leading to an increased propensity to form misfolded species [9-11]. The clinical relevance and future applications of the study of the structural variability of protein aggregates will be addressed, as it may aid the understanding of the phenotypic diversity observed in human neurodegenerative disorders.

\section{Intrinsic Disorder}

Intrinsic disorder is a natural feature of polypeptide chains, resulting in the absence of a well-defined spatial organization [5,6,12]. The presence of IDRs appears to correlate with the complexity of the living organism $[13,14]$, with half of eukaryotic proteins expected to possess at least one IDR in their sequence $[4,5,15]$. A plethora of biological functions are associated with IDRs [5,6,16], spanning from stress response [17] to high-order assembly [18] to RNA metabolism [19-21]. Broadly, IDRs may be classified in those who fold on binding or upon environmental changes and those that remain substantially unfolded [6,14,22]. A further level of variability resides in the ability of IDRs to assume non-native states of globular proteins such as the molten-globule or the coiled-coil state $[5,6,23,24]$. Being metastable and displaying weak and transient interactions [12,25], IDRs may change their structure in time, fluctuating among different low energetic levels.

Intrinsic disorder is encoded by the composition of the sequence rather than the exact string of amino acids $[26,27]$. Therefore, disordered structures may be achieved by a variety of sequences, which substantially differ from those of ordered, structured proteins $[5,6,28,29]$. Hydrophobicity, net charge resulting from the presence of a subset of specific disorder-prone amino acids ( $R, K, E, Q, S, P, G, A)$ [30] and low complexity [31] contribute in maintaining the natively unfolded structure of a protein, defining the IDR. Interacting modules of IDRs capable of undergoing disorder-to-order transitions have been defined as molecular recognition figures and short linear motifs [32-35]. Low mean hydrophobicity and high net charge have been reported to increase the disorder and reduce the solubility by reducing compaction and increasing electrostatic repulsion $[27,36,37]$. However, the presence of hydrophobic stretches was shown to increase the propensity of forming $\beta$-sheets $[26,27,38,39]$, as in the case of the non-amyloid component found in the IDR of $\alpha$-synuclein and in the low complexity C-terminal domain of TDP-43. Polar residues, such as glutamine and asparagine, are capable of forming assemblies through multiple weak side-by-side interactions [40,41], offering the driving force to form amyloids. This is the case of the polyQ stretch found in huntingtin protein in Huntington's Disease and in ataxin protein in spinocerebellar ataxia [42,43]. Similarly, most physiological fungal IDRs show a high content in $\mathrm{Q} / \mathrm{N}$ residues [12,44]. As extreme cases, homopolymeric chains such as polyglutamine, polyasparagine and polyglycine were shown to form amorphous assemblies and amyloid fibrils [45-48]. Lastly, polybasic stretches rich in arginine and lysine, displaying a high surface charge, may also produce assemblies, as in the case of the N-terminal domain of the cellular prion protein and the RGG domain of FUS [49]. Examples of strings that characterize IDRs and their properties are summarized in Table 1. 
Table 1. Features and sequences of LCDs.

\begin{tabular}{|c|c|c|c|c|}
\hline LCD Features & $\begin{array}{c}\text { Type of } \\
\text { Interaction }\end{array}$ & String Example & $\begin{array}{l}\text { Protein } \\
\text { Example }\end{array}$ & References \\
\hline $\begin{array}{l}\text { Hydrophobic- } \\
\text { enriched } \\
(\mathrm{G}, \mathrm{A}, \mathrm{I}, \mathrm{L}, \mathrm{V}, \mathrm{F}, \\
\mathrm{Y})\end{array}$ & Hydrophobic & VTNVGGAVVTGVTAVA & $\alpha$-synuclein & [26] \\
\hline Poly-Q & $\begin{array}{c}\text { weak } \\
\text { side-by-side }\end{array}$ & $\geq 8 Q$ residues & Huntingtin & [42] \\
\hline Q/N-stretches & $\begin{array}{c}\text { weak } \\
\text { side-by-side, } \\
\text { intra- and } \\
\text { inter-molecular }\end{array}$ & $\begin{array}{c}\mathrm{P} / \mathrm{QQGGYQQ/SYN} \\
\text { repeats }\end{array}$ & $\begin{array}{c}{\left[\mathrm{PSI}^{+}\right]} \\
\text {(S.cerevisiae) }\end{array}$ & {$[44]$} \\
\hline Homopolymers & H-bonds & GPG/GGX motifs & $\begin{array}{c}\text { Flag } \\
\text { (Silk protein) }\end{array}$ & [48] \\
\hline Poly-basic & $\begin{array}{l}\text { Net surface } \\
\text { charge }\end{array}$ & RGRGG repeats & FUS & [49] \\
\hline
\end{tabular}

Therefore, it is apparent that the lack of structural arrangement may be achieved through different compositions and features, ultimately converging in the ability to coalesce into higher order assemblies. Overall, low complexity offers another angle to achieve the preservation of the unfolded state, increasing the probability of forming $\beta$-structures and allowing for the formation of homomeric and heteromeric assemblies. Moreover, polymerization into supramolecular structures may differ in the state of the matter, implying different routes of aggregation.

\section{Phase Transition}

The cellular milieu is an environment crowded with macromolecules, accounting for a total intracellular concentration of up to $400 \mathrm{mg} / \mathrm{mL}$ [50,51]. Within this crowded medium with very little available space, IDRs act as hubs for the interaction with multiple partners, being either other proteins and IDRs or nucleic acids [52,53]. Dynamic interactions between IDRs and other molecules, according to the polyvalent electrostatic model $[6,18]$, allow for condensation and phase transition: once the proper conditions are met, the assembly of proteins (and eventually nucleic acids) demixes from the cytoplasm (or nucleoplasm) driven by non-covalent and transient interactions such as electrostatic, hydrophobic, hydrogen bonding, dipole - dipole, $\pi-\pi$, and cation $-\pi$ interaction $[28,54]$. This process, referred to as liquid-liquid phase separation (LLPS), leads to the formation of distinct liquid droplets within a coexisting liquid milieu, forming membraneless organelles (MLOs) [55-57]. Such structures are characterized by the high concentration of their internal components (hence defining a highly reactive environment), rapid exchange with the surrounding milieu and marked anisotropy of IDRs [24,54]. The latter indicates that, whereas in a diluted phase (e.g., the cytosol) IDRs appear to be compacted, they assume an expanded state in the liquid droplet, maximizing the chances of interactions. Accumulating knowledge $[5,6,12,58]$ is suggesting that the formation of MLOs is a rather common phenomenon in living organisms. The nucleolus [59,60], Cajal bodies [61], stress granules (SGs), RNA-protein granules and processing bodies $[62,63]$ are just a few examples of physiological MLOs that could be found in living cells. In some cases, a further phase separation may be observed within a MLO, with demixing between two slightly different viscous compartments [24,64]. In most cases, the presence of IDRs appears to be the driving factor for the transient assembly of MLOs due to their flexibility and ability to form multivalent interactions [65,66]. Moreover, MLOs may quickly assemble and disassemble as a function of the fluctuation of the environment $[8,16]$. Post-translational modifications (PTMs), namely phosphorylation, ubiquitination, acetylation, glycosylation and SUMOylation, play an important role, as the alteration of the net charge or the addition of a steric component may influence the 
state of the matter of the condensate $[67,68]$. MLO formation thus seems to be a tightly regulated process, as suggested by the positive evolutionary selection of IDR motifs. Indeed, multicellular eukaryotes own a higher amount of IDRs than monocellular eukaryotes, eubacteria and archeas $[5,15]$. Persistent liquid droplets, however, may transition into a more viscoelastic condensate (as in the case of the nucleolus [69]) and eventually form gel-like structures no longer capable of exchanging components with the surrounding environment. Although IDRs in liquid droplets retain their unfolded state, the transition into a gel-like state increases the propensity of forming $\beta$-structures, paving the way for the transition into solid structures. Upon transition into gel structures and even within MLOs, LCDs may assume $\beta$-features [24,51,54,70]. Crystallization experiments [70] suggest that LCDs in hydrogels form kinked $\beta$-sheets, owning $\beta$-sheets running parallel to the length of the crystal, with kinks of glycine or aromatic residues (termed low-complexity aromatic-rich kinked segments) stacked in ladders. Kinks prevent the interdigitation of side chains across the $\beta$-sheet interface, thus maintaining the flexibility of the structure. Nucleation of oligomers may take place in these phase separated structures, leading to the emergence of aggregates. The formation of solids from liquid droplets is sometimes referred to as "aging" $[37,66]$, which could underlie the pathogenic process associated with neurodegeneration.

\section{The Paths towards Toxicity}

The transition into a solid phase from a liquid droplet implies that a chaotic and disordered system (e.g., a liquid droplet) is organizing into ordered structures, reducing both the entropy of the system and the ability to exchange components with the environment. Whereas the formation and disassembly of MLOs is a dynamic and reversible process, solid aggregates are not able to revert back to the liquid phase and are often linked to cell death. Three hypotheses based on kinetic studies have been put forward to explain misfolding and aggregation. In the polymerization model [38,71], polymerization depends on slow and unfavorable interactions producing an oligomeric nucleus which rapidly assembles into larger polymers. Microtubule assembly, for instance, seems to follow this model [72]. The conformational hypothesis $[2,73]$ assumes that the protein is stable both as folded and misfolded. Here, conformational changes are required to produce the amyloidogenic oligomers. Lastly, the conformation/oligomerization hypothesis [74] proposes an intermediate view, with conformational changes leading to the formation of an unstable amyloidogenic oligomer, which will eventually grow to produce the solid aggregate. Following the latter hypothesis, the misfolding of LCDs into $\beta$-strands produces the active monomer, which appears to be the initial stage in the paths towards toxicity. This initial misfolding step grants the ability to perform interactions with other $\beta$-strands belonging either to the same protein or to another monomer. $\beta$-strands form hydrogen bonds among their backbone, assembling into $\beta$-sheets. During the assembly of the $\beta$-strands into sheets, various oligomeric seeds are produced due to the topology of the interactions among strands (reviewed in [39]). $\beta$-sheets bond one another through interdigitation of residues, forming steric zippers either with the same (homosteric) or different (heterosteric) sheets [11,75], stabilizing the core of the assembly. Depending on the symmetry and orientation of the $\beta$-sheet, eight theoretical steric zippers have been proposed [76], further increasing the heterogeneity of structures. Although the most common structure found in natural amyloids is the parallel in-register $\beta$-sheet $[75,76]$, other tertiary $\beta$-assemblies have been observed [9,77-79]. Starting from the same primary sequence, a protein may assume different $\beta$-enriched oligomeric conformations. These are often referred to as strains $[44,73,80,81]$, a term borrowed from virology to indicate different structures produced by the same protein specimen. A growing body of evidence is indicating oligomers as the major toxic species during the amyloidogenesis that leads to neurodegeneration [82-88]. Indeed, the potential to effectively "seed" the aggregation, referring to the ability to contact and convert monomers and hence self-propagate, seems to be an emergent property of oligomers, defined as "prion-like behaviour" (detailed in the next section). Oligomers represent an additional source of variability, as they may 
either be on-pathway or off-pathway as a function of their capacity to grow by addition of monomers. On-pathway oligomers are defined by their competence to further incorporate monomers, whereas off-pathway oligomers are stable and lack the ability to seed the aggregation [89,90]. Self-propagation of the oligomers is achieved through the addition of monomers of the same type (homotypic), forming hydrogen bonds between $\beta$-sheets that strengthen the core $[91,92]$. Stacked $\beta$-sheets from different monomers produce the characteristic quaternary cross- $\beta$-conformation that strengthens the core of the structure. Nucleating oligomers further assemble into nascent protofilaments of $2-7 \mathrm{~nm}$ in diameter $[93,94]$, which grow by incorporating monomers and associate one another by lateral interactions in various topologies. Thus, structures such as fibrils, ribbons and amorphous aggregates are observed both in different disorders and within the same pathology. In patients, the multiplicity of amyloid structures produced by the same protein may hence reflect different clinical frames and ongoing pathologies. An illustration of the stages of IDPs' aggregation and the relative energetic landscape is depicted in Figure 1.

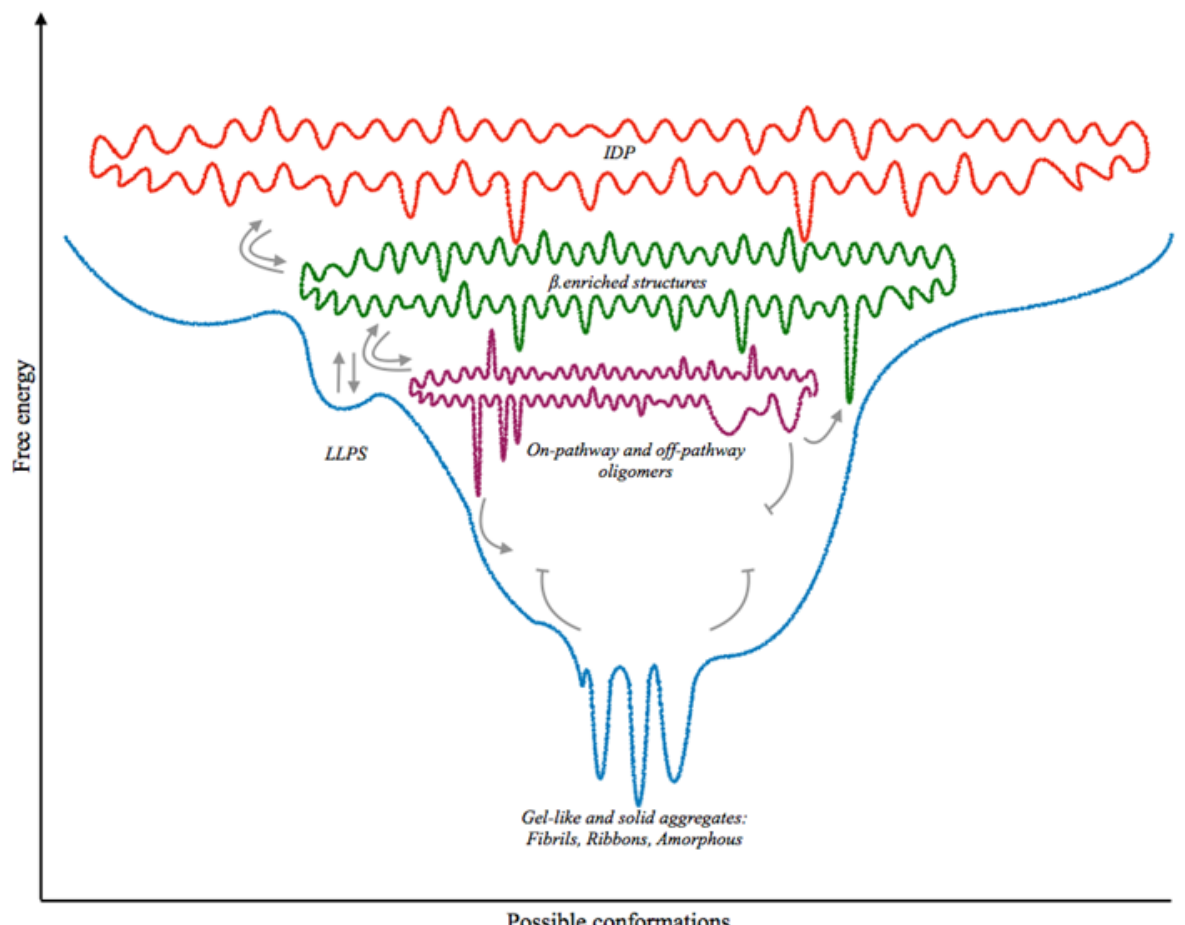

Possible conformations

Figure 1. Illustration of the energetic landscape of IDPs. Model of energetic landscape of intrinsically disordered proteins plotted as a function of free energy. Unstructured IDPs (in red) fluctuate among multiple structural states with slightly different values of free energy. Structural transition to lower free energy states involves the formation of $\beta$-enriched structures (in green). The process is reversible (gray arrows) and may depend on overlapping energetic levels. Interaction among $\beta$-structures leads to oligomers (purple). LLPS may achieved at this stage (blue line depicting the overall trend of the aggregation pathway).These structures may be on pathway for the transition to stable, solid aggregates, or may be off-pathway (depicted as wider holes) which are more stable and cannot proceed further in the path towards aggregation, but may revert back to their monomeric form (indicated by the grey arrows). The final stage of aggregation (blue) consists of solid aggregates such as fibrils, ribbons and amorphous aggregates, which represent the absolute minimum of free energy a protein can own.

\section{PrP: The Protein That Started It All}

Historically, the concept of the self-propagation and infectivity of a protein was postulated for the scrapie agent, a factor causing neurodegeneration in sheep [95]. The scrapie pathology showed remarkably similar features both to Creutzfeldt-Jakob Disease (CJD) and Kuru. The former is a rare neurodegenerative disease while the latter was an 
endemic neurodegeneration affecting the Fore tribe in the highlands of Papua New Guinea linked to their cannibalistic rituals [96]. Both Kuru and CJD were shown to be transmissible to chimpanzees and hamsters $[95,97]$. Pioneering studies demonstrated that whereas procedures aimed to hydrolyze nucleic acids were unable to lower the transmission of the scrapie agent, denaturation of proteins could reduce the infectivity $[95,98]$. The term "prion" (proteinaceous infectious particle) was proposed for the scrapie pathology as sole causative agent of the disease. Biochemically, the prion derived from scrapie infected hamsters showed an unusual resistance to non-denaturing detergents and to proteinase $\mathrm{K}$, resulting in 27-30 kDa bands after electrophoresis [95]. Improvements in the purification protocol and microscopy imaging $[99,100]$ showed the presence of rod-like structures of various sizes and shapes with tinctorial properties (binding to Congo red dye [101]) similar to those of the amyloids found in neurodegenerative diseases. Thus, the now widely accepted "protein only" hypothesis was proposed for the self-replication of the $\operatorname{PrP}[95,102]$ : its propagation requires the formation of a homotypic complex between the two molecules [103], causing the conversion of the native cellular form ( $\mathrm{PrP}-\mathrm{C})$ into the pathogenic conformation.

PrP-C is a glycosyl phosphoinositol anchored membrane glycoprotein. Its N-terminal moiety presents a variable number of octapeptide repeats enriched in Glycine residues [104-106] forming the LCD of PrP. Traditionally, low complexity regions displaying infectivity have been often referred to as prion-like domains $[1,2,5,6,8,9,73]$. For the sake of the coherence of the present work, in this review we will keep addressing these structures as LCDs. The C-terminal moiety of PrP-C forms a globular domain consisting of two $\alpha$-helices and one two-stranded antiparallel $\beta$-sheet [107], linked to the $\mathrm{N}$-terminal part by a middle hydrophobic core. Surprisingly, the amyloid region of $\mathrm{PrP}$ appears to be the folded C-terminal region (residues 90-231), which undergoes structural transition from $\alpha$-helix enriched to the typical cross- $\beta$ structure observed in amyloids [108]. In mice genetically lacking $\operatorname{PrP}\left(\mathrm{PRNP}^{0 / 0}\right.$, behaving and developing normally), the overexpression of a PrP depleted of the N-terminal octapeptide repeats restored susceptibility to infection [104]. However, it required a longer incubation time and resulted in a lower PrP titer compared to the overexpression of the full-length version. Insertion of multiple octapeptide repeats increases the flexibility of the structure, weakening the $\alpha$-helix in the C-terminal domain, thus promoting aggregation $[105,109]$. This evidence suggests that, whilst the $\mathrm{N}$-terminal $\mathrm{LCD}$ of PrP-C is not essential for prion replication, it does have an effect on the rate of prion accumulation. Outside of Kuru and CJD, other human pathologies termed transmissible spongiform encephalopathies have been linked to the misfolding of $\operatorname{PrP}[110]$, namely the variant CJD (the "mad cow" disease) [111], Gerstmann-Sträussler-Scheinker disease [112], fatal familial insomnia [113] and variably protease-sensitive prionopathy [114].

Strains of PrP were discovered in seminal studies conducted in goats intracerebrally infected with Scrapie sheep's homogenates [115]. The "drowsy" strain and the "scratching" strain were determined based on differences in inoculation time and lesion pattern. Importantly, these differences were maintained through several passages. Although sometimes referred to as strains, the main clinical and neuropathological forms of PrP are defined by a polymorphism codon 129 , either a methionine or a valine (thus producing MM, MV and $\mathrm{VV}$ ) and by their mobility shift observed by Western blot following proteinase $\mathrm{K}$ digestion, producing a type 1 fragment of $21 \mathrm{kDa}$ and a type 2 of $19 \mathrm{kDa}$ [116]. Up to six combinations are hence theoretically possible among polymorphisms and types. However, MM1 and MV1 are phenotypically identical and thus grouped in a single class (MM/MV1), whereas MV2 and MM2 cases are further divided into subgroups according to the lesion pattern: predominantly cortical lesions (MV2C an MM2C), kuru-like plaques (MV2K), or both $(\mathrm{MV} 2 \mathrm{~K}+\mathrm{C})$, and thalamic lesions (MM2T) [117]. Cases of MM1 prion type showing white matter lesions were also reported [118]. Outside the genetic variance that characterizes the dimorphism at codon 129, both types of $\operatorname{PrP}$ are found together in more than one third of the sporadic CJD patients [119,120], indicating that multiple strains may coexist in the same patient. Moreover, type 1 was further shown by conformation stability immunoassay 
to segregate into two different strains termed $\mathrm{T} 1^{20}$ and $\mathrm{T} 1^{21}$ based on their proteinase $\mathrm{K}$ resistance profile and lesion pattern [121]. Off-pathway PrP oligomers [122] and nucleic acid-mediated LLPS [123] were characterized as well, further increasing the heterogeneity of possible PrP structures. Selective vulnerability of different neuronal populations may account for the formation of different strains within the same organism, as substantiated by the differences in lesion pattern. Overall, the classical studies conducted to delve into the peculiar properties of PrP paved the way for the central role of protein misfolding and transmission in neurodegenerative diseases.

\section{6. $\alpha$-Synuclein and Synucleinopathies}

The involvement of $\alpha$-synuclein in neurodegeneration was originally identified in the attempt to characterize neurofibrillary lesions in Alzheimer's disease (AD) by the use of anti-tau antibodies, which labelled cytosolic proteins of approximately $19 \mathrm{kDa}$ [124]. Its central role in Parkinson's Disease (PD) was later revealed in genetic studies conducted on a family with early onset of PD [125] and further associated with Lewy bodies and neurites, the hallmark plaques found post-mortem in PD patients' brains.

$\alpha$-synuclein is a 140 -amino acid IDP that has a low complexity, repeated $\mathrm{N}$-terminal region, a hydrophobic central region termed non-amyloid- $\beta$ component (NAC, a LCD as well) [126] and a negatively charged, disordered C-terminal moiety [125]. The N-terminal region presents seven imperfect repeats of eleven amino acids, possessing a conserved core of a consensus sequence KTKEGV [127]. Structural analyses showed that $\alpha$-synuclein adopts through its $\mathrm{N}$-terminal part an $11 / 3$ helix lying along the surface of the membrane, half-buried in the phospholipid bilayer [128]. The role of the interaction of $\alpha$-synuclein with the membrane is still unclear, as both physiological and pathological features have been reported $[125,129]$. The formation of oligomers with a high content of $\alpha$-helices at the N-terminal moiety has been observed by Raman spectroscopy in the initial phase of $\alpha$-synuclein aggregation [130]. This heterogeneous population of spheroid oligomers is supposed to be off-pathway, as oligomers may still be in equilibrium with their monomeric counterpart, thus not obliged intermediates of the amyloid form [131]. Nonetheless, when on-pathway, the content of $\alpha$-helices is reduced upon formation of protofibrils in favor of $\beta$-sheet structures and cross- $\beta$ interactions. Solid state nuclear magnetic resonance and cryoEM imaging showed that the amyloid core of $\alpha$-synuclein oligomers presents a Greek key topology with in register hydrogen bonds along the fibril axis [132,133]. Furthermore, a recent work shows the ability of $\alpha$-synuclein to perform LLPS in vitro [134]. Here, kinetic and biophysical examinations showed that, in presence of a crowding agent such as polyethileneglycole or metallic ions and liposomes, $\alpha$-synuclein forms liquid droplets. Similarly, both PD-associated mutations and post-translational modifications (i.e., phosphorylation) caused the demixing of $\alpha$-synuclein into droplets. These assemblies appear to consist mostly of unfolded monomers, although a small amount of both oligomers and fibrils was found within droplets as well. Mutagenesis experiments pointed to possible intramolecular interactions (electrostatic and hydrophobic) between the $\mathrm{N}$-terminal and the NAC domain of $\alpha$-synuclein as a major drive for the LLPS. In aging droplets transitioning into a gel-like state, the content of monomers is reduced in favor of an increase of fibrils, whereas the oligomeric portion remained mostly identical, suggesting the existence of a steady state of the oligomers. Structurally, transmission electron microscopy imaging and CD spectra indicated that oligomers are enriched in $\alpha$-helices and, as expected, fibrils are enriched in $\beta$-sheets, indicating a dynamic equilibrium of various $\alpha$-synuclein structures within the droplet [134]. Together, these results point toward a critical role for $\alpha$-synuclein phase separation as nucleation stage for further aggregation.

Besides PD and AD (see below), the presence of $\alpha$-synuclein amyloids has been detected in a subset of neurodegenerative diseases collectively called synucleinopathies, including PD-associated dementia (PDD), dementia with Lewy Bodies (DLB) and multiple systemic atrophy (MSA). Whereas the latter is well-defined and separated from the other diseases by the presence of $\alpha$-synuclein aggregates in oligodendrocytes (termed glial 
cytoplasmic inclusions [135]), the distinction among PD, PDD and DLB is arbitrary, relying on the time difference of the onset of a series of clinical symptoms and are sometimes considered opposing edges of the same pathological spectrum [136]. However, outside the clinical frame, marked differences have been reported, such as the neurotransmitter systems involved and the presence of heterotypic aggregates [136], supporting the hypothesis that they are different diseases, probably reflecting a strain difference between the two pathologies. Both DLB and sporadic PD have been stratified in stages of progression of the pathology along connected regions with marked differences not only between PD and DLB, but even within the same pathology, defining a subset of DLB (brainstem, limbic and neocortical) by their route of spreading [137,138]. Indeed, the aggregation of $\alpha$-synuclein into different conformations, together with differences in the vulnerability of neuronal populations toward $\alpha$-synuclein aggregates, have been proposed as causative of the variety of clinical outcomes [139]. The presence of glial inclusions in MSA strongly suggests a strain typing of $\alpha$-synuclein, as MSA strains show tropism toward glial cells outside of neurons [135]. Moreover, both the aggregation rate and the morphology of the final stage of the aggregate appear to differ, with PD and MSA forming twisted structures termed ribbons and DLB forming straight aggregates, termed fibrils [140], highlighting the striking differences among these similar diseases.

\section{TDP-43}

The heterologous nuclear ribonucleoprotein TDP-43 was originally discovered for its ability to bind the trans-active response element of the human immunodeficiency virus1 [141]. Subsequently, it was detected in hyperphosphorylated and ubiquitinated state as the major component of proteinaceous deposits in post-mortem brains of patients affected by amyotrophic lateral sclerosis (ALS) and frontotemporal dementia (FTD) [142], as well as secondary pathology in other neurodegenerative diseases [143].

TDP-43 is a 414-amino acid protein containing two RNA recognition motifs, a nuclear localization and a nuclear export signal in its N-terminal moiety, and a glycine-rich (LCD) in its C-terminal moiety [144]. TDP-43 LCD presents two flanking IDRs enriched in hydrophobic $(\mathrm{V}, \mathrm{L}, \mathrm{I}, \mathrm{M})$ and aromatic $(\mathrm{F}, \mathrm{Y}, \mathrm{W})$ residues. The LCD may adapt a helix-turnhelix conformation spanning residues 320-343, followed by two antiparallel $\beta$-sheets at residues 341-366 [144]. A physiological homo-oligomeric solenoid structure, in which the $\mathrm{N}$-terminus and the C-terminus are physically separated, was proposed [145] as a structure that could halt the formation of pathogenic aggregates. Moreover, residues from 328 to 333 may form steric zippers characteristic of amyloids. Finally, the presence of aromatic residues in the IDRs allows the possibility of forming low-complexity aromatic-rich kinked segments, instrumental in the formation of MLOs [146]. Indeed, the ability of TDP-43 to perform LLPS and segregate into SGs is one of its best-characterized features [144]. TDP-43 is shuttled into the nucleus due to its nuclear localization signal, where it participates in a wide range of RNA metabolic steps [147]. Under stressful conditions, TDP-43 is exported from the nucleus to the cytoplasm, where it undergoes LLPS through its kinked helical C-terminal structure [146]. However, metabolic stress induced by lactate exposure revealed the ability of TDP-43 to coalesce into micronuclei in cultured cells [148]. Live cell imaging experiments showed that TDP-43 is able to perform nuclear LLPS in physiological conditions in a wide range of cellular models (neuronal-like cells, primary cultured mouse hippocampal neurons and human induced pluripotent stem cells). Moreover, under stressful conditions, researchers showed that TDP-43 forms LMOs in the cytoplasm both by associating to SGs and independently of SG markers, which may further evolve into gellike and solid aggregates. Morphologically, SG-associated TDP-43 appears as a spherical droplet, whilst mature TDP-43 aggregates contain amorphous filamentous and skein-like structures [149]. Together, these results indicate that TDP-43 may follow different pathways of aggregation as a function of the environment and its subcellular localization [150,151].

In the clinical practice, the heterogeneity of symptoms and neuropathological lesion patterns observed in ALS and FTD lead to the classification of five putative strains, termed 
types A to E $[152,153]$. Type A is characterized by abundant dystrophic neurites and oval shaped neuronal inclusions in cortical layer II, typically observed in FTD associated with progranulin mutations; type B shows neuronal inclusions in all cortical layers and few dystrophic neurites; type $C$ neuropathology presents long dystrophic neurites mostly found in cortical layer II of FTD cases; type D consists of widespread short dystrophic neurites and lenticular neuronal inclusions; lastly, type $\mathrm{E}$ is associated with ubiquitinnegative filamentous neuronal inclusions with wide neuroanatomical distribution, found in sporadic subset of FTD termed behavioral variant. Besides the neuropathological evidence, Western blot analyses conducted on patients' brain homogenates revealed differences in the banding pattern of the C-terminal moiety of TDP- 43 amongst various types, substantiating the putative strain typing of TDP-43. Moreover, morphologically distinct aggregates of TDP-43, reminiscent of those found in ALS, could be produced by adding extracts of ALS patients into HEK-293 cells [154].

Overall, TDP-43 displays a remarkable structural plasticity, being able to perform multiple distinct LLPS and different strains. Interestingly, TDP-43 inclusions were even found in muscle cells, a population being increasingly recognized as central in ALS etiopathogenesis $[155,156]$. This evidence indicates that TDP-43 inclusions have a tropism that goes beyond neurons.

\section{Tau and Tauopathies}

Tau is a microtubule associated protein involved in tubulin assembly and axonal transport [157]. Human full-length tau is an electric dipole, presenting an acidic $\mathrm{N}$-terminal domain followed by a proline rich region and a basic C-terminal tail. The latter owns up to four imperfectly repeated strings of 31 residues (termed R1 through R4) separated by spacer regions involved in tubulin polymerization. Indeed, it appears that the most potent inducer of tubulin polymerization is the spacer region KVQIINKK between R1 and R2 [158]. The central proline-rich region serves for intermolecular interactions such as SH3-containing proteins and peptidyl-prolyl cis/trans isomerase, whereas the N-terminal moiety projects out of the microtubule bundle to interact with other cytoskeletal elements and membranes. This domain is composed of two repeats of 29 amino acids, termed N1 and N2 [158,159]. Alternative splicing gives rise to six tau isoforms, differing in the amount of $\mathrm{N}$-terminal repeats $(0 \mathrm{~N}, 1 \mathrm{~N}$ or $2 \mathrm{~N}$ ) and the inclusion of the $\mathrm{C}$-terminal repeat $\mathrm{R} 2$ (producing $3 \mathrm{R}$ and $4 \mathrm{R}$ tau isoforms) $[157,158]$. The lack of the $\mathrm{R} 2$ sequence in $3 \mathrm{R}$ tau isoforms accounts for their weaker tubulin binding activity, as they lack the spacer KVQIINKK region $[158,160]$. The differential expression of these isoforms is a tightly regulated process both in time and space. For instance, the shortest tau isoform 0N3R is expressed during development, whereas bigger tau isoforms are mainly found in adult brains, with $1 \mathrm{~N}$ variants being the most expressed [161]. Moreover, neurons with long axons and a large diameter such as peripheral projecting neurons express an additional $\mathrm{N}$-terminal sequence producing an isoform referred as Big Tau [158,162].

Interestingly, different tau isoforms are associated with different forms of neurodegeneration, defining a subset of pathologies termed tauopathies. Hence, in Pick's Disease only $3 \mathrm{R}$ tau is found, while in corticobasal degeneration and in progressive supranuclear palsy only $4 \mathrm{R}$ tau isoforms are present in degenerative brains [157,163]. In other tauopathies both forms could be found, although with different stoichiometry, as in the case of the behavioral variant of frontotemporal dementia (with $3 \mathrm{R}$ isoform overrepresented compared to the $4 \mathrm{R})$, primary progressive aphasia and primary age-related tauopathy. Lastly, a further categorization can be made in order to distinguish between primary tauopathies (those aforementioned) and secondary tauopathies in which tau pathology is complementary to one or more other proteinaceous inclusions. This is the case of chronic traumatic encephalopathy and Alzheimer's disease, both showing an equal ratio of $3 R$ and $4 R$ isoforms along with $A \beta$ plaques.

Regardless of the domain included or excluded by alternative splicing, tau monomer is an IDP as shown both by computational and structural approaches [164,165]. Intramolec- 
ular interactions allow tau to assume a compact structure in solution, with the C-terminus folded over the microtubule binding domains and capped by the N-terminus moiety, described as a paperclip-like structure [166,167]. Transient $\beta$-structures can be formed in the R2 and R3 regions at the level of two hexapeptide motifs, termed PHF6* and PHF6 (VQIINK and VQIVYK, respectively) [168]. Anisotropy studies [169] revealed that tau monomers can reside in at least two different conformations, with the two hexapeptides either exposed or buried. However, even within these conformations, different tau strains can emerge, as observed in monomers derived from $\mathrm{AD}$ and corticobasal degeneration patients' brains [170]. Similar to other IDPs, tau was shown to demix into liquid droplets, which may be on-pathway for solid transition into aggregates driven by different intermolecular interactions [171]. Decreasing salt concentrations promotes LLPS, suggesting a major role for electrostatic interactions [172]. However, truncation experiments showed that tau demixes in a salt-independent but hexadediol sensitive manner [173]. Since hexanediol resolves liquid droplets formed upon hydrophobic interactions, these experiments indicate that tau can perform a hydrophobic-driven LLPS, mediated by its C-terminal domain, in addition to the electrostatic-driven one. Heterotypic interactions with polyanionic compounds such as nucleic acids were also reported as a way to induce tau LLPS. Indeed, a recent work demonstrated the presence of tau in nuclear speckles in association with RNA [174]. Within droplets, double electron-electron resonance spectroscopy experiments revealed that tau assumes a more extended structure, similar to that observed in anisosomes formed by TDP-43 [175]. Although CD and NMR studies showed an increased propensity for forming $\beta$ structures in liquid droplets, the cross- $\beta$ content, as analyzed by thioflavin fluorescence, was lower than those found in tau amyloids, indicating that tau LLPS may not necessarily be on-pathway for the formation of aggregates [171].

PTMs of tau have been proposed as critical events for tau phase separation and aggregation [176]. Indeed, in post-mortem patients' brains affected by tauopathies (regardless the type of pathology), tau appears to be hyperphosphorylated, ubiquitinated and acetylated. Neutralization of positive charges' lysine residues (mostly in the $\mathrm{N}$-terminal domain) by acetylation causes tau to detach from microtubule [177]. Nonetheless, hyper-acetylation dramatically reduces the ability of tau to form LLPS [178], probably due to the inability to form electrostatic interactions. Furthermore, tau could be acetylated in some of the same residues targeted by ubiquitination. Thus, a model has been proposed [163] in which acetylation competes with ubiquitination, in turn avoiding the proteasomal system and favoring tau accumulation. Phosphorylation of tau is the most abundant PTM both in physiological and pathological contexts, with more than 80 phosphorylatable residues identified to date [176]. Similar to acetylation, phosphorylation mediates the detachment of Tau from microtubules, while dephosphorylation promotes the interaction, describing a signalling mechanism that regulates cytoskeleton dynamics. Experiments conducted with hexanediol and by manipulating salt concentrations indicated that, similar to acetylation, phosphorylation of tau increases its propensity to form hydrophobic-driven LLPS and, conversely, inhibits electrostatic-driven LLPS [179]. Hyperphosphorylated tau has been observed as the major form of tau present in pathological aggregates $[157,158,163,165,176]$. Whereas some phospho-sites, such as Ser262, Ser356, and Ser396 [163,180], are found at basal levels and are likely to be key regulatory elements, others are exclusively detected in disease (e.g., Ser422, Ser396/Ser404 and Ser208 [163]).

The lingering presence of hyperphosphorylated tau inside droplets can cause the coalescence at the liquid interface, resulting in an increase of thioflavin fluorescence mirroring an increase in cross- $\beta$ structures [179]. The first event in tau oligomerization is supposed to be a dimerization mediated by the association of two monomers in antiparallel fashion, stabilized by intermolecular forces between the acidic $\mathrm{N}$-terminal domain of a monomer and the basic C-terminal end of another monomer [181]. The core of tau assemblies was shown to be made of the aggregation-prone PHF6* and PHF6 regions [166]. Upon oligomerization, tau acquires the ability to act as a template for the conversion of its monomeric version, thus establishing a prion-like mechanism of spreading [182]. Surpris- 
ingly, this feature is achieved without a canonical low complexity sequence, suggesting a convergent selection of the aggregated structure starting from different amino acidic compositions. Recently, the structure of the main components of tau neurofibrillary tangles found in different tauopathies, namely paired helical filaments and straight filaments, has been resolved by cryo-EM [183]. In AD, these structures have a C-shaped morphology, whereas in chronic traumatic encephalopathy a hydrophobic pocket is found, producing an enlarged C-shape [184]. In Pick's Disease, two types of filaments have been observed, owning an elongated morphology [185]. Lastly, corticobasal degeneration is characterized by a four-layered fold structure made up of $4 \mathrm{R}$ tau isoforms [186]. Importantly, the fibers derived from different individuals sharing the same pathology are indistinguishable one another, suggesting the existence of different strains that can differentially seed tau pathologies, resulting in variability in the neuronal structures affected, hence producing different clinical manifestations.

Overall, tdisplays high structural heterogeneity due to its alternative splicing, to the micro-environment in which aggregation takes place and to the tight regulation of PTMs. Surprisingly, the most common form of tauopathy and, in general, the most common form of dementia, Alzheimer's disease, appears to actually be a secondary tauopathy, in which tau aggregation is downstream to other pathogenic events and coexist with aggregates made up of $A \beta$ (a sine qua non conditions for AD diagnosis) and other misfolded proteins.

\section{The Curious Case of $A \beta$}

The $A \beta$ peptides are small amino acidic chains derived from the proteolytic process of the larger amyloid precursor protein (APP), whose aggregation into plaques represents the major hallmark of Alzheimer's disease along with tau-derived neurofibrillary tangles [186]. APP consists of a cytoplasmic C-terminus followed by a single transmembrane domain and an extracellular glycosylated N-terminus. Human APP can be processed through two different routes, defined as non-amyloidogenic and amyloidogenic pathways [187]. In the non-amyloidogenic processing, the enzyme $\alpha$-secretase cleaves the extracellular domain, producing a short soluble $\mathrm{N}$-terminal fragment and leaving a membrane-bound $83 \mathrm{kDa}$ fragment [187-189]. This cleavage is regulated by electrical activity and upon muscarinic acetylcholine receptor activation, suggesting a role in synaptic activity [189]. The membrane-bound fragment is further processed by the $\gamma$-secretase complex, consisting of four different proteins termed presenilin 1 and 2, nicastrin and anterior pharynx defective-2 $[187,190]$. Presenilins, the active components of the $\gamma$-secretase complex, catalyze a proteolytic cleavage on aspartate residues within the hydrophobic $83 \mathrm{kDa}$ domain, liberating a short fragment $(3 \mathrm{kDa})$ and an intracellular domain. In the amyloidogenic pathway, APP is first cleaved by $\beta$-secretase, which produces a $99 \mathrm{kDa} \mathrm{C}$-terminal moiety. This region is further processed heterogeneously by $\gamma$-secretase, resulting in the production of $A \beta$ peptides of sizes ranging from 37 to 49 amino acids $[187,191,192]$.

Although molecular dynamics simulation showed that A $\beta$ peptides are IDPs [193], transient secondary structures have been reported for various fragments. Raman and infrared spectroscopy studies showed that peptides containing residues $1-28$ fold in a polyproline-II $\alpha$-helical structure that transition into $\beta$-sheet upon binding to phospholipid bilayers [194]. Likewise, A $\beta$ fragments of various sizes were shown by NMR to display very different conformational states (see ref. [187] for an in-depth review of the structures $A \beta$ fragments may adopt in solution). The two major forms of $A \beta$ found in pathology are $A \beta 1-40$ and $A \beta$ 1-42 [195]. Although these fragments only diverge for two C-terminal residues, their structure and their ability to grow into fibrils strikingly differs [196]. Indeed, NMR-guided simulations showed that A $\beta$ 1-42 possess $\beta$-hairpins between residues 31-34 and 38-41, reducing the structural flexibility of the C-terminus [197]. On the other hand, in SDS micelle, A $\beta 1-40$ appears to be unstructured up to residue 14, followed by an $\alpha$-helix between residues 15 and 36 with a kink at the level of residues 25-27. The transition from $\alpha$-helix to coiled conformation is promoted by deprotonation of two acidic residues, in turn favoring the aggregation [198]. Overall, NMR structural studies [197] showed 
that $\mathrm{A} \beta$ peptides may populate multiple conformational levels ranging from $\alpha$-helices to $\beta$-sheets, with rapid transitions among different structural features. Along with the C-terminal sequence GGVVIA, exclusive to $A \beta 1-42$ and longer fragments, the key residues for $A \beta$ aggregation have been identified in the sequences KLVFFA at the N-terminal moiety, spanning residues 16-20 and GAIIGL $(29-34)[75,193]$. Remarkably, these three sequences are characterized by repeated residues with a hydrophobic nature.

$3 \mathrm{D}$ structures of residues $15-42$ within A $\beta$ 1-42 reveal a cross- $\beta$ sheet conformation arranged in a double horseshoe-like architecture. This structure, in which hydrophobic residues are maximally buried and residues $1-14$ show $\beta$ strand features, appears to be the most toxic and abundant in AD [187,199]. Molecular dynamics simulations combined with theoretical free energy calculations [193] suggested that the KLVFFA sequence is preferentially arranged in $\alpha$-helical fashion in the monomeric form of $A \beta$, whereas it adopts $\beta$-sheets' feature in the dimeric form. Here, $\alpha$-helices are stabilized by intramolecular hydrogen bonds while intermolecular hydrogen bondings are predominant in the $\beta$ sheet conformation. Beyond dimerization, the path of $A \beta$ peptides toward aggregation involves a widely heterogeneous population of oligomers, spanning from low molecular weight assemblies such as dimers and tetramers to midrange aggregates, protofibrils and fibrils [200]. Variations in size and arrangement of A $\beta$ 1-42 oligomers have been proposed as the main difference between late onset and rapid onset AD [201]. Moreover, solid state NMR experiments revealed $A \beta$ off-pathway oligomers as well, with a distinct structure compared to on-pathway oligomers [202]. Characterization of oligomers through different experimental approaches showed high structural variability, from discoidal shapes devoid of $\beta$ structures to antiparallel $\beta$-turn- $\beta$ motif to collapsed coil $[187,203]$. A recent paper [196] followed the aggregation of synthetic $A \beta 1-40$ and 1-42 peptides by atomic force microscopy and time-resolved thioflavin fluorescence. A drastic difference in the lag-phase (the baseline of a sigmoidal curve, representing the time required for the reaction to take place) was observed, with $A \beta 1-42$ displaying a fast rate (approx. $0.5 \mathrm{~h}$ ) of aggregation compared to the slower A $\beta$ 1-40 (approx. $20 \mathrm{~h}$ ). Micrographies performed by atomic force microscopy revealed the steps leading to the formation of fibrils. A $\beta 1-42$ appears as small spherical aggregates as baseline time point. At $0.5 \mathrm{~h}$, bigger aggregates are prevalent whilst small spheres are observed at the edge of large assemblies, indicating a growth in size by lateral association. After $1 \mathrm{~h}$ of incubation, filament structures are observed, composed by fusion among big aggregates. These results suggest that the dominant phenomenon behind $A \beta$ $1-42$ aggregation resides in the fusion among small spheroid structures. On the other hand, A $\beta$ 1-40 was observed over a longer time period, in agreement with the time resolved thioflavin assay. Although the fusion mechanism appears to be conserved in $A \beta 1-40$, a mosaic of different sizes is observed, with both big and small spheroid aggregates found at the end-stages of the reaction. When mature fibrils were assessed, $A \beta 1-42$ was shown to form thin and branched fibrils, whereas $A \beta 1-40$ produced thick and straight fibrils.

The extreme variability of $A \beta$ structures at the low scale of monomers and oligomers mirrors the diverse landscape of high order aggregates and plaques found in human brains. A $\beta$ deposits may be found either as diffuse, fibrillar, dense cored or cottonwool [204], as well as in association with cerebral blood vessels, the latter defining a pathology termed cerebral amyloid angiopathy [205]. Fibrillar and dense cored plaques often associate with dystrophic neurites and reactive astrocytes and microglia, forming a unity termed neuritic plaque [206]. These structures are hallmarks of $\mathrm{AD}$ and a mandatory presence for the definitive post-mortem diagnosis of the pathology [143]. Nonetheless, A $\beta$ aggregates poorly correlate with the severity of the disease, better recapitulated by tau inclusions [207]. Furthermore, $\mathrm{A} \beta$ plaques are found in healthy subjects as a normal consequence of aging with a frequency comparable to those found in $\mathrm{AD}$ [208]. Indeed, $\mathrm{A} \beta$ aggregates alone appear to be insufficient to trigger neurodegeneration [143]. Still, the central role of A $\beta$ in the onset of $\mathrm{AD}$ as early event for the downstream aggregation of tau is supported by overwhelming evidence based on genetic data acquired both from patients and experimental models. However, failures in therapeutic strategies focused on the amyloid cascade 
hypothesis have questioned this view [207]. Accumulated knowledge is pointing toward a multi-proteinopathy etiology of $\mathrm{AD}$, as TDP-43 inclusions and $\alpha$-synuclein aggregates are often found along with the classical $A \beta$ and tau aggregates [143,209]. Recently, prion protein oligomers have been associated with rapid onset forms of AD [210]. Moreover, in primary age-related tauopathy, tau tangles follow the same spreading pattern of AD but fail to reach the neocortex in absence of $A \beta$ plaques [211], indicating that $A \beta$ pathology is necessary for the onset of more severe stages of the disease. Conversely, $A \beta$ deposits have been well documented as co-morbidity in other prominent neurodegenerative diseases, such as DLB (85\%) and PDD (55\%) [143].

The simultaneous presence of $A \beta$ deposits in various neurodegenerative diseases, along with the presence of $A \beta$ plaques in healthy individuals and the lack of neurodegeneration associated with $A \beta$ alone, may suggest a "chaperoning" role for $A \beta$ fragments in assisting neurodegeneration, exacerbating the pathologic phenotype regardless of the main proteinaceous aggregating species. Overall, neurodegenerative diseases are multi-faceted pathologies in which IDPs interact with one another and with the environment in a narrow equilibrium between functionality and uncontrolled aggregation. Table 2 recapitulates the ability of the proteins discussed thus far to form higher molecular assemblies and summarizes the pathologies in which these forms could be found.

Table 2. Higher order structures and pathologies.

\begin{tabular}{|c|c|c|c|c|c|}
\hline Protein & Strains & $\begin{array}{c}\text { Off } \\
\text { Pathway }\end{array}$ & LLPS & $\begin{array}{l}\text { Associated } \\
\text { Neurodegen- } \\
\text { erative } \\
\text { Disease }\end{array}$ & References \\
\hline Prion protein & $\begin{array}{c}\text { Drowsy and } \\
\text { scratching in } \\
\text { sheeps; Type } 1^{20} \\
\text { Type } 1^{21} \text {, Type } 2 \\
\text { in humans }\end{array}$ & $\mathrm{V}$ & $\mathrm{V}$ & $\begin{array}{c}\text { Kuru, CJD, } \\
\text { FFI, GSS, } \\
\text { vPSPr }\end{array}$ & $\begin{array}{c}{[111-} \\
114,116,121- \\
123]\end{array}$ \\
\hline$\alpha$-synuclein & $\begin{array}{l}\text { MSA associated; } \\
\text { PD/DLB } \\
\text { associated; } \\
\text { Fibrils and } \\
\text { Ribbons }\end{array}$ & $\mathrm{V}$ & $\mathrm{V}$ & $\begin{array}{c}\text { PD, DLB, } \\
\text { MSA, AD * }\end{array}$ & {$[134,138,140]$} \\
\hline TDP-43 & Type A to Type E & / & $\mathrm{V}$ & $\begin{array}{l}\text { ALS, FTD, } \\
\mathrm{AD}^{*}\end{array}$ & $\begin{array}{c}\text { [144,149,152, } \\
153]\end{array}$ \\
\hline Tau & $\begin{array}{l}\text { CBD associated; } \\
\text { AD associated }\end{array}$ & $\mathrm{V}$ & $\mathrm{V}$ & $\begin{array}{l}\text { PiD, CBD, } \\
\text { PSP, FTD, } \\
\text { PART, AD }\end{array}$ & {$[157,170]$} \\
\hline $\mathrm{A} \beta$ & $\begin{array}{c}\text { Possibly } \\
\text { associated to AD } \\
\text { heterogeneity }\end{array}$ & V & / & $\begin{array}{c}\mathrm{AD}, \mathrm{CAA}, \\
\mathrm{PDD}^{*}, \mathrm{DLB} *\end{array}$ & {$[201,204]$} \\
\hline
\end{tabular}

\section{Protein Quality Control}

As already mentioned [7], to prevent the accumulation of potentially pathogenic aggregates, neural cells make use of a series of chaperones capable of recognizing misfolded proteins by means of the exposed hydrophobic portions, thus guiding their correct folding. Proteostasis or homeostasis of proteins, through the protein quality control system (PQC), requires the prompt degradation and eventual recycling of aggregates and misfolded proteins. PQC includes several proteolytic systems, including ubiquitin-proteasome system (UPS), chaperone-mediated autophagy (CMA), and macroautophagy [212]. 
The UPS is the system responsible for the degradation of most of the misfolded proteins. These are conjugated with ubiquitin, then deubiquitinated, linearized and introduced into the proteasome, which degrades them into smaller peptides [213]. It is important to underline that the proteasome is particularly vulnerable to protein aggregates; in fact, the passage channel of this structure has a very small diameter (just over 10-12 angstroms) and this does not allow the digestion of aggregates that are difficult to linearize. Proteotoxicity resulting from decreased UPS activity could represent potential damage to neurons [214-217].

The degradation system by CMA is able to act on misfolded cytosolic protein without interfering with normal molecules. Target proteins of CMA include aggregates showing a specific degradation signal, the KFERQ sequence and substrates generated by posttranslational modifications. These substrates may be entrusted to the CMA-mediated degradation system in lysosomes by interaction of the chaperone (mainly Hsp70 family) with the lysosome membrane molecule LAMP2A [218].

When aggregates show resistance to both the CMA and the UPS, autophagy comes into play. In the proteostasis of post mitotic neurons the role of autophagy is of fundamental importance. In fact, in these cells the cytotoxic proteins cannot be diluted by cell division and, consequently, a good quality control must be entrusted to specialized mechanisms. Efficacy of autophagy clearance has been shown to play an important role for neuronal homeostasis and maintenance. Thus, the restoration or promotion of autophagic function has been proposed as one possible approach to delay aging, including brain aging [219]. Moreover, several studies have shown that a number of signaling molecules responsible for regulating neuronal activity are localized in membrane lipid rafts [220], for example, neuroglobin, which is found in the lipid raft and is involved in neuronal survival mechanisms [221].

As a consequence, alterations in lipid rafts' components have been hypothesized to contribute to the loss of neural function and potentially to the cell death/cell survival or autophagy balance associated with neurodegeneration. In particular, lipid rafts at mitochondria associated membrane (MAM) level are structures involved in a number of key metabolic functions, shown to be altered in neurodegenerations such as $\mathrm{AD}, \mathrm{PD}$ and ALS [222,223]. Garofalo et al. demonstrated that MAM-associated lipid rafts could represent a physical and functional platform operating during the early steps of autophagic process. In fact, GD3, a core component of lipid raft-like microdomains, has been detected in immature autophagosomes associated with phosphatidylinositol 3-phosphate PI3P and LC3-II, as well as in autophagolysosomes associated with LAMP1 [224]. In addition, disruption of mitochondrial dynamics by the knocking down of strategic molecules associated to MAM's lipid rafts including MFN2, GD3 or ERLIN1 significantly prevented autophagosome biogenesis and maturation [225]. In light of this evidence, a dysregulation during autophagosome maturation might drive the accumulation of protein aggregates and increase neurodegeneration (Figure 2).

It is possible to direct misfolded proteins prone to aggregation to the autophagic mechanism for lysosomal degradation thanks to the involvement of molecules that function as adapters, such as p62 and NBR1 [226]. P62, normally inactive, is activated by binding to other molecules, mostly at the level of the ER. After the accumulation of non-degradable autophagic cargoes, the chaperone molecules residing in the ER and participating in this signaling chain are arginylated and, via the $\mathrm{N}$-terminal arginine residue, bind to the $\mathrm{ZZ}$ domain of p62 in the cytosol. Once bound, p62 undergoes a conformational modification that induces its polymerization and the interaction with LC3-II, a molecule anchored on the membrane of autophagosomes [218]. The autophagosome thus begins its load and, once completed, fuses with the lysosome to form the autolysosome, for the degradation by lysosomal hydrolases of both, load and p62. 


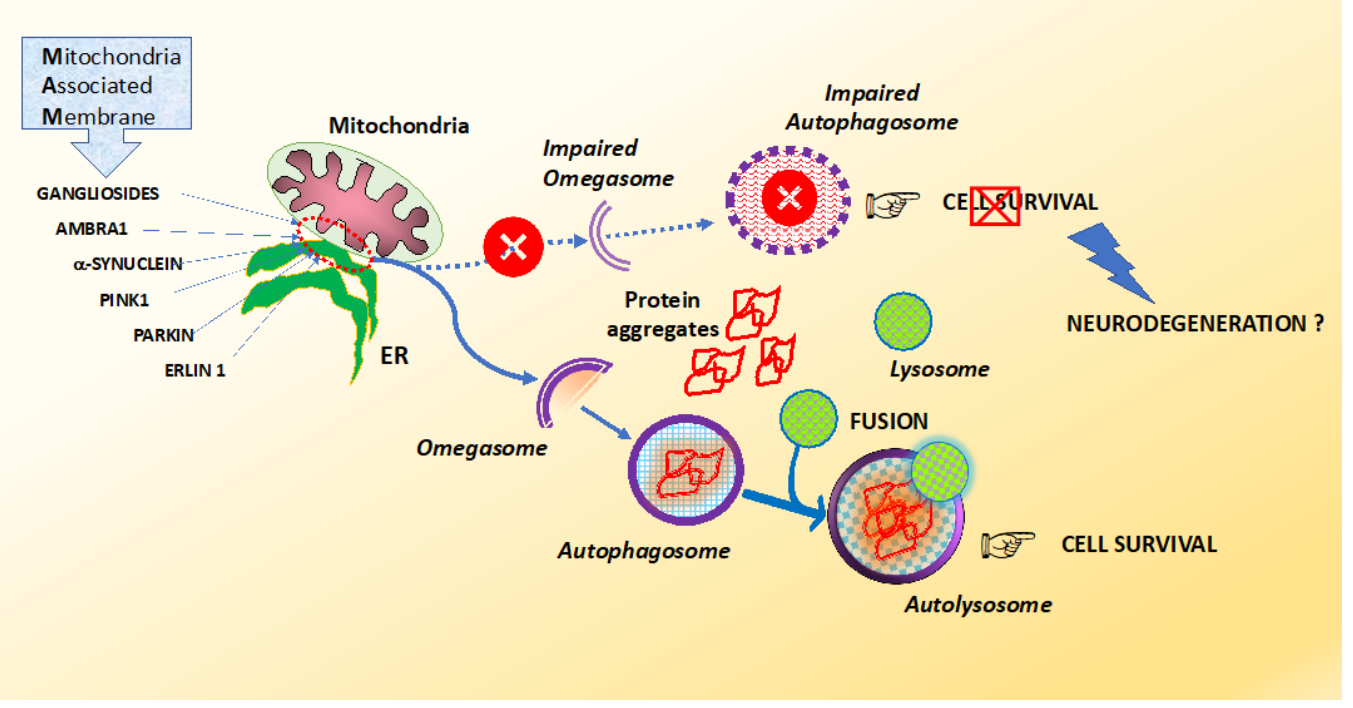

Figure 2. Efficient autophagy is required to remove protein aggregates and prevent neurodegeneration. Vesicle nucleation is regulated by molecular components associated to mitochondria-associated endoplasmic reticulum (ER) membranes (MAM), some of which are enriched in the lipid raft of MAM, including gangliosides, AMBRA1 and ERLIN1. Autophagosome formation is necessary to prevent the accumulation of damaged proteins and to ensure cell survival. The alteration of the autophagic machinery during the early stages prevents the maturation of omegasomes by hindering the autophagic flux and the clearance of aggregated proteins, thus contributing to neurodegeneration.

The failure of the PQC system to remove misfolded proteins in the nervous system is the biochemical process behind most neurodegenerative diseases. During aging, deterioration in the PQC systems causes the failure of protein degradation, which may result in the accumulation of misfolded proteins. The successive modifications of structure and aggregation represent in many cases hallmarks of neurodegenerative diseases.

In light of this, it is clear that molecules involved in the clearance of misfolded proteins could represent new pharmacological targets, for example, by controlling the activation of CMA chaperones and adapters, as well as using autophagy inducers, which could be included in future therapeutic strategies for the improvement of neurodegenerative diseases.

\section{Clinical Outlook and Concluding Remarks}

Protein aggregation is an emerging concept in biology. Accumulating knowledge is suggesting that a convergent evolution has positively selected IDRs. Living organisms exploited the intrinsic property of IDRs to form amyloids to their advantage, incorporating it as a key signaling mechanism. Functional amyloids have indeed been documented throughout evolution, from yeasts to mammals [44,227]. Intriguingly, amyloid species of proteins associated with neurodegeneration may, in principle, serve a physiological role as well. For instance, proteinase K-resistant PrP was found in response to chronic morphine withdrawal in rats [228], whereas reversible, hyperphosphorylated tau tangles were found in brains of hibernating mammals [229]. The dysregulation of a physiological function associated with the aggregated state may thus represent the mechanism behind the abundance of IDR sequences found in proteins associated with neurodegenerative diseases (Table 3). 
Table 3. Amyloidogenic sequences.

\begin{tabular}{|c|c|c|c|}
\hline Protein & Sequence(s) Features & LCD Sequence(s) & References \\
\hline \multirow{2}{*}{ Prion protein } & N-terminal octapeptide repeats & ${ }^{51}$ PQGGTWGQ ${ }^{58}$ & [105] \\
\hline & C-terminal hydrophobic stretch & ${ }^{112}$ MAGAAAAGAVVGGLGGYVLGSAM ${ }^{134}$ & {$[106]$} \\
\hline \multirow{3}{*}{$\alpha$-synuclein } & N-terminal imperfectly repeated LCD & consensus sequence: KTKEGV & [127] \\
\hline & & ${ }^{61}$ EQVTNVGGAVVTGVTAVAQK & \\
\hline & C-terminal hydrophobic NAC domain & $\begin{array}{l}\text { TVEGAGSIAAATGFVKKDQL } \\
\text { GKNEE }^{105}\end{array}$ & [126] \\
\hline \multirow{13}{*}{ TDP-43 } & \multirow{13}{*}{ Long C-terminal glycine-rich LCD } & IDR1: & \multirow{13}{*}[144,145]{} \\
\hline & & ${ }^{216}$ RAFAFVTFADDQIAQSL & \\
\hline & & CGEDLIIKGISVHISNAEP & \\
\hline & & KHNSNRQLERSGRFGGNPGG & \\
\hline & & FGNQGGFGNSRGGG & \\
\hline & & AGLGNNQGSNMGGGM 310 & \\
\hline & & $\begin{array}{c}\text { Amyloidogenic core: } \\
{ }^{311} \text { NFGAFSINPAMMAAAQAA }\end{array}$ & \\
\hline & & LQSSWGMMGMLASQQNQS & \\
\hline & & GPSGNNQNQGNMQ 360 & \\
\hline & & IDR2: & \\
\hline & & ${ }^{361}$ REPNQAFGSGNNSYSGSNS & \\
\hline & & GAAIGWGSASNAGSGSG & \\
\hline & & FNGGFGSSMDSKSSGWGM 414 & \\
\hline Tau & $\begin{array}{c}\text { C-terminal hydrophobic PHF6 and } \\
\text { PHF6* motifs }\end{array}$ & ${ }^{275} \mathrm{VQIINK}^{280} ;{ }^{306} \mathrm{VQIVYK}^{311}$ & {$[166,168]$} \\
\hline \multirow{2}{*}{$\mathrm{A} \beta$} & N-terminal Hydrophobic-aromatic & ${ }^{16} \mathrm{KLVFFA}^{21}$ & \multirow{2}{*}{ [75] } \\
\hline & C-terminal Hydrophobic & ${ }^{29}$ GAIIGL $^{34} ;{ }^{29}$ GGVVIA $^{34}$ & \\
\hline
\end{tabular}

The understanding of the link between structural plasticity of proteins and neurodegeneration has led researchers to investigate this phenomenon as both a diagnostic and therapeutic tool. Particularly, the advent of dyes capable of specifically labelling aggregating structures $[101,230]$, together with the exploitation of the prion-like seeded conversion mechanism, produced outstanding results in the early and differential diagnosis of neurodegenerative diseases. Protein misfolding cyclic amplification and real-time quaking-induced conversion assays have been applied to an increasing number of pathologies, starting with prion-related pathologies $[231,232]$ and expanding to synucleinopathies $[233,234]$, tauopathies and AD [235-237] and TDP-43-related pathologies [238], yielding a very a high diagnostic accuracy from ex vivo samples. Moreover, evidence of strain typing, as in the case of prion pathologies and synucleinopathies, has been documented with these technologies [239-241]. This group of evidence is particularly important in the clinical practice, as often neurodegenerative pathologies show overlapping phenotypes. For instance, atypical parkinsonism, characterized by motor symptoms derived from au misfolding and aggregation, have been accurately differentiated from synucleinopathies according to real-time quaking-induced conversion results [234]. Along with kinetic analyses, improvements in antibody-mediated detection of specific conformation are paving the way for the usage of a combination ratio of aggregation-related and neuronal damage proteins as diagnostic biomarkers [242-244]. On the other side, anti-amyloidogenic compounds are being studied as potential therapeutics [245-247]. Neurodegenerative diseases are still uncurable conditions. However, the basic knowledge of the biological role of the arrays of conformations may further aid the development of effective diagnostic and therapeutic tools by uncovering paths that could be relevant for the etiopathogenesis of neurodegenerative disorders.

High-throughput screening, combined with computer-based drug design, are employed for the discovery of novel therapeutic agents [248,249]. These methodologies are able to probe hundreds of thousands of drugs per day by scaling down the equipment and biological materials required to probe molecules. Typically, few hundreds of "hits" are selected for further studies on biocompatibility and availability, resulting in tens of molecules ultimately selected as "leads" for the development of a treatment. For instance, 
by applying biochemical high-throughput screening, combined with Thioflavin-T readouts, aminothienopyridazines were found to exert anti-amyloidogenic activity on tau aggregation by inhibition of fibril assembly [250].

However, high-throughput screening is still hindered by several factors. Most notably, cellular and biochemical platforms are simplified surrogates of the physiological environment that do not fully replicate the complexity of the organism. Efforts in the optimization of the system aimed to overcome this issue have led to the development of lab-on-a-chip and organ-on-a-chip technologies [251]. These newly developed exciting tools are miniaturized microfluidic perfusion devices in which primary cells can be grown for an extended time, allowing the screening of drug candidates in an environment similar to physiology, preserving cell-to-cell interactions, energy supply and removal of catabolites [248].

As we are just beginning to understand the phenomenon of phase separation and protein aggregation, the direction of the molecular pathogenetic study, an expression of basic science, seems right. This approach makes predictable a future in which these devastating diseases may be early and accurately diagnosed, so that personalized and disease-modifying therapies could slow down the insurgence of pathologies.

Author Contributions: Conceptualization, N.C.; C.V.; A.F.; R.M.; original draft preparation, N.C.; review and editing, A.F.; C.V.; S.S.; I.S.; R.M.; visualization, S.S.; I.S.; C.V.; A.F.; V.M.; T.G.; M.S.; R.M.; supervision, C.V.; A.F.; R.M.; M.S. All authors have read and agreed to the published version of the manuscript.

Funding: This work was supported: Fondazione Umberto Veronesi (individual Grant 2021 to NC), Italian Ministry of Education, University and Research (MIUR) (PRIN 2017 SNRXH3 to RM), AriSLA through the HyperALS project (A.F.); AFM-Telethon project n. 2018 and AFM-Telethon project n. 21021 (A.F.); Ministry of Health, Italy-United States of America. 2020- “Whole transcriptome analysis in models of extended healthy lifespan after spermidine treatment"-n.PGR01040 (C.V.).

Conflicts of Interest: The authors declare no conflict of interest.

$\begin{array}{ll}\text { Abbreviations } \\ \text { IDR } & \text { Intrinsically disordered region } \\ \text { IDP } & \text { Intrinsically disordered protein } \\ \text { LCD } & \text { Low complexity domain } \\ \text { PrP } & \text { Prion protein } \\ \text { A } \beta & \text { Amyloid } \beta \\ \text { TDP-43 } & \text { TAR DNA binding protein 43 } \\ \text { LLPS } & \text { Liquid-liquid phase separation } \\ \text { MLO } & \text { Membraneless Organelle } \\ \text { SG } & \text { Stress Granules } \\ \text { PTM } & \text { Post-translational modification } \\ \text { CJD } & \text { Creutzfeldt-Jakob disease } \\ \text { PrP-C } & \text { Cellular prion protein } \\ \text { AD } & \text { Alzheimer's Disease } \\ \text { PD } & \text { Parkinson's Disease } \\ \text { NAC } & \text { Non- Amyloid } \beta \text { Component } \\ \text { PDD } & \text { Parkinson's Disease Dementia } \\ \text { DLB } & \text { Dementia with Lewy Bodies } \\ \text { MSA } & \text { Multiple System Atrophy } \\ \text { ALS } & \text { Amyotrophic Lateral Sclerosis } \\ \text { FTD } & \text { Frontotemporal Dementia }\end{array}$




$\begin{array}{ll}\text { APP } & \text { Amyloid Precursor Protein } \\ \text { FFI } & \text { Fatal Familial Insomnia } \\ \text { GSS } & \text { Gerstmann-Sträussler-Scheinker } \\ \text { vPSPr } & \text { variably Protease-Sensitive Prionopathy } \\ \text { PiD } & \text { Pick's Disease } \\ \text { CBD } & \text { Corticobasal Degeneration } \\ \text { PSP } & \text { Progressive Supranuclear Palsy } \\ \text { PART } & \text { Primary Age-Related Tauopathy } \\ \text { CAA } & \text { Cerebral Amyloid Angiopathy } \\ \text { PQC } & \text { Protein Quality Control } \\ \text { UPS } & \text { Ubiquitin-proteasome system } \\ \text { CMA } & \text { Chaperone-mediated autophagy } \\ \text { MAM } & \text { Mitochondria Associated Membrane }\end{array}$

\section{References}

1. Soto, C. Protein misfolding and disease; protein refolding and therapy. FEBS Lett. 2001, 498, 204-207. [CrossRef]

2. Soto, C. Unfolding protein misfolding in neurodegenerative diseases. Nat. Rev. Neurosci. 2003, 4, 49-60. [CrossRef]

3. Foit, L.; Morgan, G.J.; Kern, M.J.; Steimer, L.R.; von Hacht, A.A.; Titchmarsh, J.; Warriner, S.L.; Radford, S.E.; Bradwell, J.C.A. Optimizing protein stability in vivo. Mol. Cell. 2009, 36, 861-871. [CrossRef]

4. Ward, J.J.; McGuffin, L.J.; Buxton, B.F.; Jones, D.T. Prediction and functional analysis of native disorder in proteins from the three kingdoms of life. J. Mol. Biol. 2004, 337, 635-645. [CrossRef] [PubMed]

5. Dunker, A.K.; Silman, I.; Uversky, V.N.; Sussman, J.L. Function and structure of inherently disordered proteins. Curr. Opin. Struct. Biol. 2008, 18, 756-764. [CrossRef] [PubMed]

6. Uversky, V.N. Intrinsic Disorder, Protein-Protein Interactions, and Disease. Adv. Protein. Chem. Struct. Biol. 2018, 110, 85-121. [CrossRef]

7. Hegyi, H.; Tompa, P. Intrinsically Disordered Proteins Display No Preference for Chaperone Binding In Vivo. PLoS Comput. Biol. 2008, 4, e1000017. [CrossRef] [PubMed]

8. March, Z.M.; King, O.D.; Shorter, J. Prion-like domains as epigenetic regulators, scaffolds for subcellular organization, and drivers of neurodegenerative disease. Brain Res. 2016, 1647, 9-18. [CrossRef]

9. Chiti, F.; Dobson, C.M. Protein Misfolding, Amyloid Formation, and Human Disease: A Summary of Progress Over the Last Decade. Annu. Rev. Biochem. 2017, 86, 27-68. [CrossRef] [PubMed]

10. Sekijima, Y.; Wiseman, R.L.; Matteson, J.; Hammarström, P.; Miller, S.R.; Sawkar, A.R.; Balch, W.E.; Kelly, J.W. The biological and chemical basis for tissue-selective amyloid disease. Cell 2005, 121, 73-85. [CrossRef] [PubMed]

11. Harrison, A.F.; Shorter, J. RNA-binding proteins with prion-like domains in health and disease. Biochem. J. 2017, 474, 1417-1438. [CrossRef]

12. Wallman, A.; Kesten, C. Common Functions of Disordered Proteins across Evolutionary Distant Organisms. Int. J. Mol. Sci. 2020, 21, 2105. [CrossRef] [PubMed]

13. Babu, M.M. The contribution of intrinsically disordered regions to protein function, cellular complexity, and human disease. Biochem. Soc. Trans. 2016, 44, 1185-1200. [CrossRef]

14. Vymetal, J.; Vondrášek, J.; Hlouchová, K. Sequence Versus Composition: What Prescribes IDP Biophysical Properties? Entropy 2019, 21, 654. [CrossRef] [PubMed]

15. Peng, Z.; Yan, J.; Fan, X.; Mizianty, M.J.; Xue, B.; Wang, K.; Hu, G.; Uversky, V.N.; Kurgan, L. Exceptionally abundant exceptions: Comprehensive characterization of intrinsic disorder in all domains of life. Cell Mol. Life Sci. 2015, 72, 137-151. [CrossRef]

16. Wright, P.E.; Dyson, H.J. Intrinsically Disordered Proteins in Cellular Signaling and Regulation. Nat. Rev. Mol. Cell Biol. 2015, 16, 18-29. [CrossRef] [PubMed]

17. Chavali, S.; Gunnarsson, A.; Babu, M.M. Intrinsically Disordered Proteins Adaptively Reorganize Cellular Matter During Stress. Trends Biochem. Sci. 2017, 42, 410-412. [CrossRef]

18. Uversky, V.N. The multifaceted roles of intrinsic disorder in protein complexes. FEBS Lett. 2015, 589, 2498-2506. [CrossRef]

19. Calabretta, S.; Richard, S. Emerging Roles of Disordered Sequences in RNA-Binding Proteins. Trends Biochem. Sci. 2015, 40, 662-672. [CrossRef]

20. Basu, S.; Bahadur, R.P. A structural perspective of RNA recognition by intrinsically disordered proteins. Cell Mol. Life Sci. 2016, 73, 4075-4084. [CrossRef]

21. Zagorvic, B.; Bartonek, L.; Polyansky, A.A. RNA-protein interactions in an unstructured context. FEBS Lett. 2018, 592, 2901-2916. [CrossRef]

22. Kuznetsova, I.M.; Turoverov, K.K.; Uversky, V.N. What Macromolecular Crowding Can Do to a Protein. Int. J. Mol. Sci. 2014, 15, 23090-23140. [CrossRef] [PubMed]

23. Crick, S.L.; Ruff, K.M.; Garai, K.; Frieden, C.; Pappu, R.V. Unmasking the roles of N- and C-terminal flanking sequences from exon 1 of huntingtin as modulators of polyglutamine aggregation. Proc. Natl. Acad. Sci. USA 2013, 110, 20075-20080. [CrossRef] 
24. Bergeron-Sandoval, L.P.; Safaee, N.; Michnick, S.W. Mechanisms and Consequences of Macromolecular Phase Separation. Cell 2016, 165, 1067-1079. [CrossRef] [PubMed]

25. Cieplak, M.; Chwastyk, M.; Mioduszewski, L.; de Aquino, B.R.H. Transient knots in intrinsically disordered proteins and neurodegeneration. Prog. Mol. Biol. Transl. Sci. 2020, 174, 79-103. [CrossRef] [PubMed]

26. Das, S.; Pal, U.; Sad, S.; Bagga, K.; Roy, A.; Mrigwani, A.; Maiti, N.C. Sequence Complexity of Amyloidogenic Regions in Intrinsically Disordered Human Proteins. PLoS ONE 2014, 9, e89781. [CrossRef]

27. Kumari, B.; Kumar, R.; Kumar, M. Low complexity and disordered regions of proteins have different structural and amino acid preferences. Mol. Biosyst. 2015, 11, 585-594. [CrossRef] [PubMed]

28. Martin, E.W.; Mittag, T. Relationship of Sequence and Phase Separation in Protein Low-Complexity Regions. Biochemistry. 2018, 57, 2478-2487. [CrossRef]

29. Pak, C.W.; Kosno, M.; Holehouse, A.S.; Padrick, S.B.; Mittal, A.; Ali, R.; Yunus, A.A.; Liu, D.R.; Pappu, R.V.; Rosen, M.K. Sequence Determinants of Intracellular Phase Separation by Complex Coacervation of a Disordered Protein. Mol. Cell. 2016, 63, 72-85. [CrossRef]

30. Zarin, T.; Strome, B.; Nguyen Ba, A.N.; Alberti, S.; Forman-Kay, J.D.; Moses, A.M. Proteome-wide signatures of function in highly diverged intrinsically disordered regions. eLife 2019, 8, e46883. [CrossRef]

31. Uversky, V.N. Paradoxes and wonders of intrinsic disorder: Complexity of simplicity. Intrinsically Disord. Proteins 2016, 4, e1135015. [CrossRef]

32. Disfani, F.M.; Hsu, W.L.; Mizianty, M.J.; Oldfield, C.J.; Xue, B.; Dunker, A.K.; Uversky, V.N.; Kurgan, L. MoRFpred, a Computational Tool for Sequence-based Prediction and Characterization of Short Disorder-to-order Transitioning Binding Regions in Proteins. Bioinformatics 2012, 28, i75-i83. [CrossRef] [PubMed]

33. Fuxreiter, M.; Tompa, P.; Simon, I. Local structural disorder imparts plasticity on linear motifs. Bioinformatics 2007, 23, 950-956. [CrossRef] [PubMed]

34. Edwards, R.J.; Davey, N.E.; Shields, D.C. SLiMFinder: A probabilistic method for identifying over-represented, convergently evolved, short linear motifs in proteins. PLoS ONE 2007, 2, e967. [CrossRef] [PubMed]

35. Yruela, I.; Oldfield, C.J.; Niklas, K.J.; Keith Dunker, A. Evidence for a Strong Correlation Between Transcription Factor Protein Disorder and Organismic Complexity. Genome Biol. Evol. 2017, 9, 1248-1265. [CrossRef] [PubMed]

36. Uversky, V.N.; Gillespie, J.R.; Fink, A.L. Why are "natively unfolded" proteins unstructured under physiologic conditions? Proteins 2000, 41, 415-427. [CrossRef]

37. Babinchak, W.M.; Haider, R.; Dumm, B.K.; Sarkar, P.; Surewicz, K.; Choi, J.K.; Surewicz, W.K. The role of liquid-liquid phase separation in aggregation of the TDP-43 low-complexity domain. J. Biol. Chem. 2019, 294, 6306-6317. [CrossRef]

38. Šarić, A.; Michaels, T.C.T.; Zaccone, A.; Knowles, T.P.J.; Frenkel, D. Kinetics of spontaneous filament nucleation via oligomers: Insights from theory and simulation. J. Chem. Phys. 2016, 145, 211926. [CrossRef]

39. Fomicheva, A.; Ross, E. From Prions to Stress Granules: Defining the Compositional Features of Prion-Like Domains That Promote Different Types of Assemblies. Int. J. Mol. Sci. 2021, 22, 1251. [CrossRef]

40. Halfmann, R.; Alberti, S.; Krishnan, R.; Lyle, N.; O’Donnell, C.W.; King, O.D.; Berger, B.; Pappu, R.V.; Lindquist, S. Opposing Effects of Glutamine and Asparagine Govern Prion Formation by Intrinsically Disordered Proteins. Mol. Cell. 2011, 43, 72-84. [CrossRef]

41. Bousset, L.; Savistchenko, J.; Melki, R. Assembly of the asparagine- and glutamine-rich yeast prions into protein fibrils. Curr. Alzheimer Res. 2008, 5, 251-259. [CrossRef]

42. Jayaraman, M.; Kodali, R.; Sahoo, B.; Thakur, A.K.; Mayasundari, A.; Mishra, R.; Peterson, C.B.; Wetzel, R. Slow amyloid nucleation via $\alpha$-helix-rich oligomeric intermediates in short polyglutamine-containing huntingtin fragments. J. Mol. Biol. 2012, 415, 881-899. [CrossRef]

43. Elden, A.C.; Kim, H.J.; Hart, M.P.; Chen-Plotkin, A.S.; Johnson, B.S.; Fang, X.; Armakola, M.; Geser, F.; Greene, R.; Lu, M.M.; et al. Ataxin-2 intermediate-length polyglutamine expansions are associated with increased risk for ALS. Nature 2010, 466, 1069-1075. [CrossRef]

44. Krishnan, R.; Lindquist, S.L. Structural insights into a yeast prion illuminate nucleation and strain diversity. Nature 2005, 435, 765-772. [CrossRef] [PubMed]

45. Inayathullah, M.; Tan, A.; Jeyaraj, R.; Lam, J.; Cho, N.J.; Liu, C.W.; Manoukian, M.A.; Ashkan, K.; Mahmoudi, M.; Rajadas, J. Self-assembly and sequence length dependence on nanofibrils of polyglutamine peptides. Neuropeptides. 2016, 57, 71-83. [CrossRef] [PubMed]

46. Peters, T.W.; Huang, M. Protein Aggregation and Polyasparagine-Mediated Cellular Toxicity in Saccharomyces cerevisiae. Prion 2007, 1, 144-153. [CrossRef] [PubMed]

47. Crick, F.H.; Rich, A. Structure of polyglycine II. Nature 1955, 176, 780-781. [CrossRef] [PubMed]

48. Perea, G.B.; Riekel, C.; Guinea, G.V.; Madurga, R.; Daza, R.; Burghammer, M.; Hayashi, C.; Elices, M.; Plaza, G.R.; Pérez-Rigueiro, J. Identification and dynamics of polyglycine II nanocrystals in Argiope trifasciata flagelliform silk. Sci. Rep. 2013, 3, 3061. [CrossRef] [PubMed]

49. Ozdilek, B.A.; Thompson, V.F.; Ahmed, N.S.; White, C.I.; Batey, R.T.; Schwartz, J.C. Intrinsically disordered RGG/RG domains mediate degenerate specificity in RNA binding. Nucleic Acids Res. 2017, 45, 7984-7996. [CrossRef] [PubMed] 
50. McGuffee, S.R.; Elcock, A.H. Diffusion, crowding \& protein stability in a dynamic molecular model of the bacterial cytoplasm. PLoS Comput. Biol. 2010, 6, e1000694. [CrossRef]

51. André, A.A.M.; Spruijt, E. Liquid-Liquid Phase Separation in Crowded Environments. Int. J. Mol. Sci. 2020, 21, 5908. [CrossRef]

52. Dunker, A.K.; Cortese, M.S.; Romero, P.; Iakoucheva, L.M.; Uversky, V.N. Flexible nets. The roles of intrinsic disorder in protein interaction networks. FEBS J. 2005, 272, 5129-5148. [CrossRef]

53. Hu, G.; Wu, Z.; Uversky, V.N.; Kurgan, L. Functional Analysis of Human Hub Proteins and Their Interactors Involved in the Intrinsic Disorder-Enriched Interactions. Int. J. Mol. Sci. 2017, 18, 2761. [CrossRef] [PubMed]

54. Majumdar, A.; Dogra, P.; Maity, S.; Mukhopadhyay, S. Liquid-Liquid Phase Separation Is Driven by Large-Scale Conformational Unwinding and Fluctuations of Intrinsically Disordered Protein Molecules. J. Phys. Chem. Lett. 2019, 10, 3929-3936. [CrossRef]

55. Aumiller, W.M., Jr.; Keating, C.D. Experimental models for dynamic compartmentalization of biomolecules in liquid organelles: Reversible formation and partitioning in aqueous biphasic systems. Adv. Colloid Interface Sci. 2017, 239, 75-87. [CrossRef] [PubMed]

56. Mitrea, D.M.; Kriwacki, R.W. Phase separation in biology; functional organization of a higher order. Cell Commun. Signal 2016, 14, 1. [CrossRef] [PubMed]

57. Hayashi, Y.; Ford, L.K.; Fioriti, L.; McGurk, L.; Zhang, M. Liquid-Liquid Phase Separation in Physiology and Pathophysiology of the Nervous System. J. Neurosci. 2021, 41, 834-844. [CrossRef] [PubMed]

58. Uversky, V.N. Protein intrinsic disorder-based liquid-liquid phase transitions in biological systems: Complex coacervates and membrane-less organelles. Adv. Colloid. Interface Sci. 2017, 239, 97-114. [CrossRef]

59. Mitrea, D.M.; Cika, J.A.; Guy, C.S.; Ban, D.; Banerjee, P.R.; Stanley, C.B.; Nourse, A.; Deniz, A.A.; Kriwacki, R.W. Nucleophosmin integrates within the nucleolus via multi-modal interactions with proteins displaying R-rich linear motifs and rRNA. eLife 2016, 5, e13571. [CrossRef]

60. Falahati, H.; Wieschaus, E. Independent active and thermodynamic processes govern the nucleolus assembly in vivo. Proc. Natl Acad. Sci. USA 2017, 114, 1335-1340. [CrossRef]

61. Dundr, M. Nuclear bodies: Multifunctional companions of the genome. Curr. Opin. Cell Biol. 2012, 24, 415-422. [CrossRef] [PubMed]

62. Banani, S.F.; Lee, H.O.; Hyman, A.A.; Rosen, M.K. Biomolecular condensates: Organizers of cellular biochemistry. Nat. Rev. Mol. Cell Biol. 2017, 18, 285-298. [CrossRef] [PubMed]

63. Wheeler, J.R.; Matheny, T.; Jain, S.; Abrisch, R.; Parker, R. Distinct stages in stress granule assembly and disassembly. eLife 2016, 5, e18413. [CrossRef]

64. Feric, M.; Vaidya, N.; Harmon, T.S.; Mitrea, D.M.; Zhu, L.; Richardson, T.M.; Kriwacki, R.W.; Pappu, R.V.; Brangwynne, C.P. Coexisting liquid phases underlie nucleolar sub-compartments. Cell 2016, 165, 1686-1697. [CrossRef] [PubMed]

65. Wang, J.; Choi, J.M.; Holehouse, A.S.; Lee, H.O.; Zhang, X.; Jahnel, M.; Maharana, S.; Lemaitre, R.; Pozniakovsky, A.; Drechsel, D.; et al. A Molecular Grammar Governing the Driving Forces for Phase Separation of Prion-like RNA Binding Proteins. Cell 2018, 174, 688-699. [CrossRef] [PubMed]

66. Boeynaems, S.; Alberti, S.; Fawzi, N.L.; Mittag, T.; Polymenidou, M.; Rousseau, F.; Schymkowitz, J.; Shorter, J.; Wolozin, B.; Van Den Bosch, L.; et al. Protein Phase Separation: A New Phase in Cell Biology. Trends Cell Biol. 2018, 28, 420-435. [CrossRef] [PubMed]

67. Riback, J.A.; Katanski, C.D.; Kear-Scott, J.L.; Pilipenko, E.V.; Rojek, A.E.; Sosnick, T.R.; Drummond, D.A. Stress-Triggered Phase Separation Is an Adaptive, Evolutionarily Tuned Response. Cell 2017, 168, 1028-1040.e9. [CrossRef] [PubMed]

68. Owen, I.; Shewmaker, F. The Role of Post-Translational Modifications in the Phase Transitions of Intrinsically Disordered Proteins. Int. J. Mol. Sci. 2019, 20, 5501. [CrossRef]

69. Yao, R.W.; Xu, G.; Wang, Y.; Shan, L.; Luan, P.F.; Wang, Y.; Wu, M.; Yang, L.Z.; Xing, Y.H.; Yang, L.; et al. Nascent Pre-rRNA Sorting via Phase Separation Drives the Assembly of Dense Fibrillar Components in the Human Nucleolus. Mol. Cell. 2019, 76, 767-783.e11. [CrossRef]

70. Hughes, M.P.; Sawaya, M.R.; Boyer, D.R.; Goldschmidt, L.; Rodriguez, J.A.; Cascio, D.; Chong, L.; Gonen, T.; Eisenberg, D.S. Atomic structures of low-complexity protein segments reveal kinked $\beta$ sheets that assemble networks. Science 2018, 359, 698-701. [CrossRef] [PubMed]

71. Davis, J.K.; Sindi, S.S. A study in nucleated polymerization models of protein aggregation. Appl. Math. Lett. 2016, 72, 1555-1578. [CrossRef]

72. Hernańdez-Vega, A.; Braun, M.; Scharrel, L.; Jahnel, M.; Wegmann, S.; Hyman, B.T.; Alberti, S.; Diez, S.; Hyman, A.A. Local Nucleation of Microtubule Bundles through Tubulin Concentration into a Condensed Tau Phase. Cell Rep. 2017, 20, $2304-2312$. [CrossRef] [PubMed]

73. Soto, C.; Pritzkow, S. Protein misfolding, aggregation, and conformational strains in neurodegenerative diseases. Nat. Neurosci. 2018, 21, 1332-1340. [CrossRef] [PubMed]

74. Carrell, R.W.; Gooptu, B. Conformational changes and disease-Serpins, prions and Alzheimer's. Curr. Opin. Struct. Biol. 1999, 8, 799-809. [CrossRef]

75. Sawaya, M.R.; Sambashivan, S.; Nelson, R.; Ivanova, M.I.; Sievers, S.A.; Apostol, M.I.; Thompson, M.J.; Balbirnie, M.; Wiltzius, J.J.; McFarlane, H.T.; et al. Atomic structures of amyloid cross-beta spines reveal varied steric zippers. Nature 2007, 447, 453-457. [CrossRef] [PubMed] 
76. Reik, R. The Three-Dimensional Structures of Amyloids. Cold Spring Harb. Perspect. Biol. 2017, 9, a023572. [CrossRef]

77. Seuring, C.; Verasdonck, J.; Gath, J.; Ghosh, D.; Nespovitaya, N.; Wälti, M.A.; Maji, S.K.; Cadalbert, R.; Güntert, P.; Meier, B.H.; et al. The three-dimensional structure of human $\beta$-endorphin amyloid fibrils. Nat. Struct. Mol. Biol. 2020, 27, 1178-1184. [CrossRef]

78. Shi, Y.; Murzin, A.G.; Falcon, B.; Epstein, A.; Machin, J.; Tempest, P.; Newell, K.L.; Vidal, R.; Garringer, H.J.; Sahara, N.; et al. Cryo-EM structures of tau filaments from Alzheimer's disease with PET ligand APN-1607. Acta Neuropathol. 2021, 141, 697-708. [CrossRef]

79. Moran, S.D.; Zhang, T.O.; Decatur, S.M.; Zanni, M.T. Amyloid fiber formation in human $\gamma$ D-Crystallin induced by UV-B photodamage. Biochemistry 2013, 52, 6169-6181. [CrossRef]

80. Daskalov, A.; Martinez, D.; Coustou, V.; El Mammeri, N.; Berbon, M.; Andreas, L.B.; Bardiaux, B.; Stanek, J.; Noubhani, A.; Kauffmann, B.; et al. Structural and molecular basis of cross-seeding barriers in amyloids. Proc. Natl. Acad. Sci. USA 2021, 118, e2014085118. [CrossRef]

81. Scialò, C.; De Cecco, E.; Manganotti, P.; Legname, G. Prion and Prion-Like Protein Strains: Deciphering the Molecular Basis of Heterogeneity in Neurodegeneration. Viruses 2019, 11, 261. [CrossRef]

82. Kayed, R.; Lasagna-Reeves, C.A. Molecular Mechanisms of Amyloid Oligomers Toxicity. J. Alzheimer's Dis. 2012, 33, S67-S78. [CrossRef]

83. Lemarre, P.; Pujo-Menjouet, L.; Sindi, S.S. Generalizing a mathematical model of prion aggregation allows strain coexistence and co-stability by including a novel misfolded species. J. Math. Biol. 2019, 78, 465-495. [CrossRef]

84. Watts, J.C.; Condello, C.; Stöhr, J.; Oehler, A.; Lee, J.; DeArmond, S.J.; Lannfelt, L.; Ingelsson, M.; Giles, K.; Prusiner, S.B. Serial propagation of distinct strains of A $\beta$ prions from Alzheimer's disease patients. Proc. Natl. Acad. Sci. USA 2014, 111, 10323-10328. [CrossRef] [PubMed]

85. Chen, J.; Zaer, S.; Drori, P.; Zamel, J.; Joron, K.; Kalisman, N.; Lerner, E.; Dokholyan, N.V. The structural heterogeneity of $\alpha$-synuclein is governed by several distinct subpopulations with interconversion times slower than milliseconds. Structure 2021, 29, 1-17. [CrossRef]

86. Gyparaki, M.T.; Arab, A.; Sorokina, E.M.; Santiago-Ruiz, A.N.; Bohrer, C.H.; Xiao, J.; Lakadamyali, M. Tau forms oligomeric complexes on microtubules that are distinct from tau aggregates. Proc. Natl. Acad. Sci. USA 2021, 118, e2021461118. [CrossRef] [PubMed]

87. Peng, C.; Gathagan, R.J.; Covell, D.J.; Medellin, C.; Stieber, A.; Robinson, J.L.; Zhang, B.; Pitkin, R.M.; Olufemi, M.F.; Luk, K.C.; et al. Cellular milieu imparts distinct pathological $\alpha$-synuclein strains in $\alpha$-synucleinopathies. Nature 2018, 557, 558-563. [CrossRef]

88. Laferrière, F.; Maniecka, Z.; Pérez-Berlanga, M.; Hruska-Plochan, M.; Gilhespy, L.; Hock, E.M.; Wagner, U.; Afroz, T.; Boersema, P.J.; Barmettler, G.; et al. TDP-43 extracted from frontotemporal lobar degeneration subject brains displays distinct aggregate assemblies and neurotoxic effects reflecting disease progression rates. Nat. Neurosci. 2019, 22, 65-77. [CrossRef]

89. Karamanos, T.K.; Jackson, M.P.; Calabrese, A.N.; Goodchild, S.C.; Cawood, E.E.; Thompson, G.S.; Kalverda, A.P.; Hewitt, E.W.; Radford, S.E. Structural mapping of oligomeric intermediates in an amyloid assembly pathway. eLife 2019, 8, e46574. [CrossRef]

90. Dear, A.J.; Meisl, G.; Šarić, A.; Michaels, T.C.T.; Kjaergaard, M.; Linse, S.; Knowles, T.P.J. Identification of on- and off-pathway oligomers in amyloid fibril formation. Chem. Sci. 2020, 11, 6236-6247. [CrossRef]

91. Dear, A.J.; Michaels, T.C.T.; Meisl, G.; Klenerman, D.; Wu, S.; Perrett, S.; Linse, S.; Dobson, C.M.; Knowles, T.P.J. Kinetic diversity of amyloid oligomers. Proc. Natl. Acad. Sci. USA 2020, 117, 12087-12094. [CrossRef]

92. Collins, S.R.; Douglass, A.; Vale, R.D.; Weissman, J.S. Mechanism of Prion Propagation: Amyloid Growth Occurs by Monomer Addition. PLoS Biol. 2004, 2, e321. [CrossRef] [PubMed]

93. Close, W.; Neumann, M.; Schmidt, A.; Hora, M.; Annamalai, K.; Schmidt, M.; Reif, B.; Schmidt, V.; Grigorieff, N.; Fändrich, M. Physical basis of amyloid fibril polymorphism. Nat. Commun. 2018, 9, 699. [CrossRef] [PubMed]

94. Makowski, L. The Structural Basis of Amyloid Strains in Alzheimer's Disease. ACS Biomater. Sci. Eng. 2020, 6, $2498-2505$. [CrossRef] [PubMed]

95. Prusiner, S.B. Novel proteinaceous infectious particles cause scrapie. Science 1982, 216, 36-144. [CrossRef] [PubMed]

96. Gajdusek, D.C. Unconventional viruses and the origin and disappearance of kuru. Science 1977, 197, 943-960. [CrossRef] [PubMed]

97. Kimberlin, R.H.; Walker, C.A. Evidence that the transmission of one source of scrapie agent to hamsters involves separation of agent strains from a mixture. J. Gen. Virol. 1978, 39, 487-496. [CrossRef] [PubMed]

98. Prusiner, S.B.; McKinley, M.P.; Groth, D.F.; Bowman, K.A.; Mock, N.I.; Cochran, S.P.; Masiarz, F.R. Scrapie agent contains a hydrophobic protein. Proc. Natl. Acad. Sci. USA 1981, 78, 6675-6679. [CrossRef] [PubMed]

99. McKinley, M.P.; Braunfeld, M.B.; Bellinger, C.G.; Prusiner, S.B. Molecular Characteristics of Prion Rods Purified from ScrapieInfected Hamster Brains. J. Infect. Dis. 1986, 54, 110-120. [CrossRef] [PubMed]

100. Nguyen, J.T.; Inouye, H.; Baldwin, M.A.; Fletterick, R.J.; Cohen, F.E.; Prusiner, S.B.; Kirschner, D.A. X-ray diffraction of scrapie prion rods and PrP peptides. J. Mol. Biol. 1995, 252, 412-422. [CrossRef]

101. Caughey, B.; Race, R.E. Potent inhibition of scrapie-associated PrP accumulation by Congo red. J. Neurochem. 1992, 59, 768-771. [CrossRef]

102. Griffith, J.S. Self-replication and scrapie. Nature 1967, 215, 1043-1044. [CrossRef] 
103. Prusiner, S.B.; Scott, M.; Foster, D.; Pan, K.M.; Groth, D.; Mirenda, C.; Torchia, M.; Yang, S.L.; Serban, D.; Carlson, G.A.; et al. Transgenetic studies implicate interactions between homologous PrP isoforms in scrapie prion replication. Cell 1990, 63, 673-686. [CrossRef]

104. Flechsig, E.; Shmerling, D.; Hegyi, I.; Raeber, A.J.; Fischer, M.; Cozzio, A.; von Mering, C.; Aguzzi, A.; Weissmann, C. Prion protein devoid of the octapeptide repeat region restores susceptibility to scrapie in PrP knockout mice. Neuron 2000, 27, 399-408. [CrossRef]

105. Yu, K.H.; Huang, M.Y.; Lee, Y.R.; Lin, Y.K.; Chen, H.R.; Lee, C.I. The Effect of Octapeptide Repeats on Prion Folding and Misfolding. Int. J. Mol. Sci. 2021, 22, 1800. [CrossRef] [PubMed]

106. Harrison, C.F.; Lawson, V.A.; Coleman, B.M.; Kim, Y.S.; Masters, C.L.; Cappai, R.; Barnham, K.J.; Hill, A.F. Conservation of a glycine-rich region in the prion protein is required for uptake of prion infectivity. J. Biol. Chem. 2010, 285, 20213-20223. [CrossRef] [PubMed]

107. Zahn, R.; Liu, T.; Lührs, T.; Riek, R.; von Schroetter, F.; López García, F.; Billeter, M.; Calzolai, G.; Wider, K.; Wüthrich, K. NMR solution structure of the human prion protein. Proc. Natl. Acad. Sci. USA 2000, 97, 145-150. [CrossRef] [PubMed]

108. Baral, P.K.; Yin, J.; Aguzzi, A.; James, M.N.G. Transition of the prion protein from a structured cellular form (PrP C) to the infectious scrapie agent (PrP Sc). Protein Sci. 2019, 28, 2055-2063. [CrossRef]

109. Moore, R.A.; Herzog, C.; Errett, J.; Kocisko, D.A.; Arnold, K.M.; Hayes, S.F.; Priola, S.A. Octapeptide repeat insertions increase the rate of protease-resistant prion protein formation. Protein Sci. 2006, 15, 609-619. [CrossRef]

110. Schmitz, M.; Dittmar, K.; Llorens, F.; Gelpi, E.; Ferrer, I.; Schulz-Schaeffer, W.J.; Zerr, I. Hereditary Human Prion Diseases: An Update. Mol. Neurobiol. 2017, 54, 4138-4149. [CrossRef]

111. Brandel, J.P.; Knight, R. Variant Creutzfeldt-Jakob Disease. Handb. Clin. Neurol. 2018, 153, 191-205. [CrossRef] [PubMed]

112. Cracco, L.; Xiao, X.; Nemani, S.K.; Lavrich, J.; Cali, I.; Ghetti, B.; Notari, S.; Surewicz, W.K.; Gambetti, P. Gerstmann-SträusslerScheinker disease revisited: Accumulation of covalently-linked multimers of internal prion protein fragments. Acta Neuropathol. Commun. 2019, 7, 85. [CrossRef]

113. Llorens, F.; Zarranz, J.J.; Fischer, A.; Zerr, I.; Ferrer, I. Fatal Familial Insomnia: Clinical Aspects and Molecular Alterations. Curr. Neurol. Neurosci. Rep. 2017, 17, 30. [CrossRef] [PubMed]

114. Notari, S.; Appleby, B.S.; Gambetti, P. Variably protease-sensitive prionopathy. Handb. Clin. Neurol. 2018, 153, 175-190. [CrossRef]

115. Pattison, I.H.; Millson, G.C. Scrapie produced experimentally in goats with special reference to the clinical syndrome. J. Comp. Pathol. 1961, 71, 101-109. [CrossRef]

116. Zanusso, G.; Monaco, S.; Pocchiari, M.; Caughey, B. Advanced tests for early and accurate diagnosis of Creutzfeldt-Jakob disease Nat. Rev. Neurol. 2016, 12, 325-333. [CrossRef]

117. Nemani, S.K.; Xiao, X.; Cali, I.; Cracco, L.; Puoti, G.; Nigro, M.; Lavrich, J.; Bharara Singh, A.; Appleby, B.S.; Sim, V.L.; et al. A novel mechanism of phenotypic heterogeneity in Creutzfeldt-Jakob disease. Acta Neuropathol. Commun. 2020, 8, 85. [CrossRef] [PubMed]

118. Rossi, M.; Saverioni, D.; Di Bari, M.; Baiardi, S.; Lemstra, A.W.; Pirisinu, L.; Capellari, S.; Rozemuller, A.; Nonno, R.; Parchi, P. Atypical Creutzfeldt-Jakob disease with PrP-amyloid plaques in white matter: Molecular characterization and transmission to bank voles show the M1 strain signature. Acta Neuropathol. Commun. 2017, 5, 87. [CrossRef]

119. Cassard, H.; Huor, A.; Espinosa, J.C.; Douet, J.Y.; Lugan, S.; Aron, N.; Vilette, D.; Delisle, M.B.; Marín-Moreno, A.; Peran, P.; et al Prions from Sporadic Creutzfeldt-Jakob Disease Patients Propagate as Strain Mixtures. mBio 2020, 11, e00393-20. [CrossRef]

120. Cali, I.; Puoti, G.; Smucny, J.; Curtiss, P.M.; Cracco, L.; Kitamoto, T.; Occhipinti, R.; Cohen, M.L.; Appleby, B.S.; Gambetti, P. Co-existence of $\mathrm{PrP}^{\mathrm{D}}$ types 1 and 2 in sporadic Creutzfeldt-Jakob disease of the VV subgroup: Phenotypic and prion protein characteristics. Sci. Rep. 2020, 10, 1503. [CrossRef] [PubMed]

121. Cali, I.; Espinosa, J.C.; Nemani, S.K.; Marin-Moreno, A.; Camacho, M.V.; Aslam, R.; Kitamoto, T.; Appleby, B.S.; Torres, J.M.; Gambetti, P. Two distinct conformers of PrPD type 1 of sporadic Creutzfeldt-Jakob disease with codon 129VV genotype faithfully propagate in vivo. Acta Neuropathol. Commun. 2021, 9, 55. [CrossRef]

122. Combet, S.; Cousin, F.; Rezaei, H.; Noinville, S. Membrane interaction of off-pathway prion oligomers and lipid-induced onpathway intermediates during prion conversion: A clue for neurotoxicity. Biochim. Biophys. Acta Biomembr. 2019, 1861, 514-523. [CrossRef] [PubMed]

123. Tange, H.; Ishibashi, D.; Nakagaki, T.; Taguchi, Y.; Kamatari, Y.O.; Ozawa, H.; Nishida, N. Liquid-liquid phase separation of full-length prion protein initiates conformational conversion in vitro. J. Biol. Chem. 2021, 2, 100367. [CrossRef] [PubMed]

124. Uéda, K.; Fukushima, K.; Masliah, E.; Xia, Y.; Iwai, A.; Yoshimoto, M.; Otero, D.A.; Kondo, J.; Ihara, Y.; Saitoh, T. Molecular cloning of cDNA encoding an unrecognized component of amyloid in Alzheimer disease. Proc. Natl. Acad. Sci. USA 1993, 90, 11282. [CrossRef] [PubMed]

125. Spillantini, M.G.; Schmidt, M.L.; Lee, V.M.; Trojanowski, J.Q.; Jakes, R.; Goedert, M. Alpha-synuclein in Lewy bodies. Nature 1997, 388, 839-840. [CrossRef]

126. Weinreb, P.H.; Zhen, W.; Poon, A.W.; Conway, K.A.; Lansbury, P.T., Jr. NACP, a protein implicated in Alzheimer's disease and learning, is natively unfolded. Biochemistry 1996, 35, 13709-13715. [CrossRef] [PubMed]

127. Dettmer, U.; Newman, A.J.; von Saucken, V.E.; Bartels, T.; Selkoe, D. KTKEGV repeat motifs are key mediators of normal $\alpha$-synuclein tetramerization: Their mutation causes excess monomers and neurotoxicity. Proc. Natl. Acad. Sci. USA 2015, 112, 9596-9601. [CrossRef] [PubMed] 
128. Jao, C.C.; Der-Sarkissian, A.; Chen, J.; Langen, R. Structure of membrane-bound alpha-synuclein studied by site-directed spin labeling. Proc. Natl. Acad. Sci. USA 2004, 101, 8331-8336. [CrossRef] [PubMed]

129. Tofaris, G.K.; Spillantini, M.G. Physiological and pathological properties of $\alpha$-synuclein. Cell. Mol. Life Sci. 2007, 64, $2194-2201$. [CrossRef]

130. Apetri, M.M.; Maiti, N.C.; Zagorski, M.G.; Carey, P.R.; Anderson, V.E. Secondary Structure of a-Synuclein Oligomers: Characterization by Raman and Atomic Force Microscopy. J. Mol. Biol. 2006, 6, 63-71. [CrossRef] [PubMed]

131. Fagerqvist, T.; Näsström, T.; Ihse, E.; Lindström, V.; Sahlin, C.; Tucker, S.M.; Kasaryan, A.; Karlsson, M.; Nikolajeff, F.; Schell, H.; et al. Off-pathway $\alpha$-synuclein oligomers seem to alter $\alpha$-synuclein turnover in a cell model but lack seeding capability in vivo. Amyloid 2013, 20, 233-244. [CrossRef] [PubMed]

132. Li, B.; Ge, P.; Murray, K.A.; Sheth, P.; Zhang, M.; Nair, G.; Sawaya, M.R.; Shin, W.S.; Boyer, D.R.; Ye, S.; et al. Cryo-EM of full-length $\alpha$-synuclein reveals fibril polymorphs with a common structural kernel. Nat. Commun. 2018, 9, 3609. [CrossRef] [PubMed]

133. Tuttle, M.D.; Comellas, G.; Nieuwkoop, A.J.; Covell, D.J.; Berthold, D.A.; Kloepper, K.D.; Courtney, J.M.; Kim, J.K.; Barclay, A.M.; Kendall, A.; et al. Solid-state NMR structure of a pathogenic fibril of full-length human $\alpha$-synuclein. Nat. Struct. Mol. Biol. 2016, 23, 409-415. [CrossRef]

134. Ray, S.; Singh, N.; Kumar, R.; Patel, K.; Pandey, S.; Datta, D.; Mahato, J.; Panigrahi, R.; Navalkar, A.; Mehra, S.; et al. $\alpha$-Synuclein aggregation nucleates through liquid-liquid phase separation. Nat. Chem. 2020, 12, 705-716. [CrossRef]

135. Prusiner, S.B.; Woerman, A.L.; Mordes, D.A.; Watts, J.C.; Rampersaud, R.; Berry, D.B.; Patel, S.; Oehler, A.; Lowe, J.K.; Kravitz, S.N.; et al. Evidence for $\alpha$-synuclein prions causing multiple system atrophy in humans with parkinsonism. Proc. Natl. Acad. Sci. USA 2015, 112, E5308-E5317. [CrossRef] [PubMed]

136. Jellinger, K.A.; Korczyn, A.D. Are dementia with Lewy bodies and Parkinson's disease dementia the same disease? BMC Med. 2018, 16, 34. [CrossRef] [PubMed]

137. Braak, H.; Del Tredici, K.; Rüb, U.; de Vos, R.A.; Jansen Steur, E.N.; Braak, E. Staging of brain pathology related to sporadic Parkinson's disease. Neurobiol. Aging 2013, 24, 197-211. [CrossRef]

138. Alafuzoff, I.; Ince, P.G.; Arzberger, T.; Al-Sarraj, S.; Bell, J.; Bodi, I.; Bogdanovic, N.; Bugiani, O.; Ferrer, I.; Gelpi, E.; et al. Staging/typing of Lewy body related alpha-synuclein pathology: A study of the BrainNet Europe Consortium. Acta Neuropathol. 2009, 117, 635-652. [CrossRef] [PubMed]

139. Sulzer, D.; Surmeier, D.J. Neuronal vulnerability, pathogenesis, and Parkinson's disease. Mov. Disord. 2013, 28, 715-724. [CrossRef]

140. Peelaerts, W.; Baekelandt, V. $\alpha$-Synuclein strains and the variable pathologies of synucleinopathies. J. Neurochem. 2016, 139 (Suppl. 1), 256-274. [CrossRef]

141. Ou, S.H.; Wu, F.; García-Martínez, L.F.; Gaynor, R.B. Cloning and characterization of a novel cellular protein, TDP-43, that binds to human immunodeficiency virus type 1 TAR DNA sequence motifs. J. Virol. 1995, 69, 3584-3596. [CrossRef]

142. Neumann, M.; Sampathu, D.M.; Kwong, L.K.; Truax, A.C.; Micsenyi, M.C.; Chou, T.T.; Bruce, J.; Schuck, T.; Grossman, M.; Clark, C.M.; et al. Ubiquitinated TDP-43 in frontotemporal lobar degeneration and amyotrophic lateral sclerosis. Science 2006, 314, 130-133. [CrossRef]

143. Spires-Jones, T.L.; Attems, J.; Thal, D.R. Interactions of pathological proteins in neurodegenerative diseases. Acta Neuropathol. 2017, 134, 187-205. [CrossRef] [PubMed]

144. Tziortzouda, P.; Van Den Bosch, L.; Hirth, F. Triad of TDP43 control in neurodegeneration: Autoregulation, localization and aggregation. Nat. Ver. Neurosci. 2021, 22, 197-208. [CrossRef] [PubMed]

145. Afroz, T.; Hock, E.M.; Ernst, P.; Foglieni, C.; Jambeau, M.; Gilhespy, L.A.B.; Laferriere, F.; Maniecka, Z.; Plückthun, A.; Mittl, P.; et al. Functional and dynamic polymerization of the ALS-linked protein TDP-43 antagonizes its pathologic aggregation. Nat. Commun. 2017, 8, 45. [CrossRef] [PubMed]

146. Pakravan, D.; Michiels, E.; Bratek-Skicki, A.; De Decker, M.; Van Lindt, J.; Alsteens, D.; Derclaye, S.; Van Damme, P.; Schymkowitz, J.; Rousseau, F.; et al. Liquid-Liquid Phase Separation Enhances TDP-43 LCD Aggregation but Delays Seeded Aggregation. Biomolecules 2021, 11, 548. [CrossRef] [PubMed]

147. Tollervey, J.R.; Curk, T.; Rogelj, B.; Briese, M.; Cereda, M.; Kayikci, M.; König, J.; Hortobágyi, T.; Nishimura, A.L.; Zupunski, V.; et al. Characterizing the RNA targets and position-dependent splicing regulation by TDP-43. Nat. Neurosci. 2011, 14, 452-458. [CrossRef] [PubMed]

148. Droppelmann, C.A.; Campos-Melo, D.; Moszczynski, A.J.; Amzil, H.; Strong, M.J. TDP-43 aggregation inside micronuclei reveals a potential mechanism for protein inclusion formation in ALS. Sci. Rep. 2019, 9, 19928. [CrossRef]

149. Gasset-Rosa, F.; Lu, S.; Yu, H.; Chen, C.; Melamed, Z.; Guo, L.; Shorter, J.; Da Cruz, S.; Cleveland, D.W. Cytoplasmic TDP-43 De-mixing Independent of Stress Granules Drives Inhibition of Nuclear Import, Loss of Nuclear TDP-43, and Cell Death. Neuron 2019, 102, 339-357.e7. [CrossRef]

150. Suk, T.R.; Rousseaux, M.W.C. The role of TDP-43 mislocalization in amyotrophic lateral sclerosis. Mol. Neurodegener. 2020, 15, 45. [CrossRef]

151. Bozzo, F.; Salvatori, I.; Iacovelli, F.; Mirra, A.; Rossi, S.; Cozzolino, M.; Falconi, M.; Valle, C.; Carrì, M.T. Structural insights into the multi-determinant aggregation of TDP-43 in motor neuron-like cells. Neurobiol Dis. 2016, 94, 63-72. [CrossRef] [PubMed]

152. Lee, E.B.; Porta, S.; Michael Baer, G.; Xu, Y.; Suh, E.; Kwong, L.K.; Elman, L.; Grossman, M.; Lee, V.M.; Irwin, D.J.; et al. Expansion of the classification of FTLD-TDP: Distinct pathology associated with rapidly progressive frontotemporal degeneration. Acta Neuropathol. 2017, 134, 65-78. [CrossRef] 
153. Ayers, J.I.; Borchelt, D.R. Phenotypic diversity in ALS and the role of poly-conformational protein misfolding. Acta Neuropathol. 2020, 15. [CrossRef] [PubMed]

154. Smethurst, P.; Newcombe, J.; Troakes, C.; Simone, R.; Chen, Y.R.; Patani, R.; Sidle, K. In vitro prion-like behaviour of TDP-43 in ALS. Neurobiol. Dis. 2016, 96, 236-247. [CrossRef] [PubMed]

155. Scaricamazza, S.; Salvatori, I.; Ferri, A.; Valle, C. Skeletal Muscle in ALS: An Unappreciated Therapeutic Opportunity? Cells 2021, 10, 525. [CrossRef]

156. Picchiarelli, G.; Dupuis, L. Role of RNA Binding Proteins with prion-like domains in muscle and neuromuscular diseases. Cell Stress. 2020, 4, 76-91. [CrossRef] [PubMed]

157. Arendt, T.; Stieler, J.T.; Holzer, M. Tau and tauopathies. Brain Res. Bull. 2016, 126, 238-292. [CrossRef]

158. Kolarova, M.; García-Sierra, F.; Bartos, A.; Ricny, J.; Ripova, D. Structure and pathology of tau protein in Alzheimer disease. Int. J. Alzheimer's Dis. 2012, 2012, 731526. [CrossRef]

159. Derreumaux, P.; Man, V.H.; Wang, J.; Nguyen, P.H. Tau R3-R4 Domain Dimer of the Wild Type and Phosphorylated Ser356 Sequences. I. In Solution by Atomistic Simulations. J. Phys. Chem. B 2020, 124, 2975-2983. [CrossRef]

160. Goedert, M.; Jakes, R. Expression of separate isoforms of human tau protein: Correlation with the tau pattern in brain and effects on tubulin polymerization. EMBO J. 1990, 9, 4225-4230. [CrossRef]

161. Tuerde, D.; Kimura, T.; Miyasaka, T.; Furusawa, K.; Shimozawa, A.; Hasegawa, M.; Ando, K.; Hisanaga, S.I. Isoform-independent and -dependent phosphorylation of microtubule-associated protein tau in mouse brain during postnatal development. J. Biol. Chem. 2018, 293, 1781-1793. [CrossRef]

162. Couchie, D.; Mavilia, C.; Georgieff, I.S.; Liem, R.K.; Shelanski, M.L.; Nunez, J. Primary structure of high molecular weight tau present in the peripheral nervous system. Proc. Natl. Acad. Sci. USA 1992, 89, 4378-4381. [CrossRef] [PubMed]

163. Silva, M.C.; Haggarty, S.J. Tauopathies: Deciphering Disease Mechanisms to Develop Effective Therapies. Int. J. Mol. Sci. 2020, 21, 8948. [CrossRef] [PubMed]

164. Nguyen, P.H.; Derreumaux, P. Structures of the intrinsically disordered A $\beta$, tau and $\alpha$-synuclein proteins in aqueous solution from computer simulations. Biophys. Chem. 2020, 264, 106421. [CrossRef]

165. Zhu, S.; Shala, A.; Bezginov, A.; Sljoka, A.; Audette, G.; Wilson, D.J. Hyperphosphorylation of intrinsically disordered tau protein induces an amyloidogenic shift in its conformational ensemble. PLoS ONE 2015, 10, e0120416. [CrossRef] [PubMed]

166. Zeng, Y.; Yang, J.; Zhang, B.; Gao, M.; Su, Z.; Huang, Y. The structure and phase of tau: From monomer to amyloid filament. Cell Mol. Life Sci. 2021, 78, 1873-1886. [CrossRef]

167. Jeganathan, S.; von Bergen, M.; Brutlach, H.; Steinhoff, H.J.; Mandelkow, E. Global hairpin folding of tau in solution. Biochemistry 2006, 45, 2283-2293. [CrossRef] [PubMed]

168. Yang, J.; Agnihotri, M.V.; Huseby, C.J.; Kuret, J.; Singer, S.J. A theoretical study of polymorphism in VQIVYK fibrils. Biophys. J. 2021, 120, 1396-1416. [CrossRef] [PubMed]

169. Foote, A.K.; Manger, L.H.; Holden, M.R.; Margittai, M.; Goldsmith, R.H. Time-resolved multirotational dynamics of single solution-phase tau proteins reveals details of conformational variation. Phys. Chem. Chem. Phys. 2019, 21, 1863-1871. [CrossRef]

170. Narasimhan, S.; Guo, J.L.; Changolkar, L.; Stieber, A.; McBride, J.D.; Silva, L.V.; He, Z.; Zhang, B.; Gathagan, R.J.; Trojanowski, J.Q.; et al. Pathological Tau Strains from Human Brains Recapitulate the Diversity of Tauopathies in Nontransgenic Mouse Brain. J. Neurosci. 2017, 37, 11406-11423. [CrossRef]

171. Ambadipudi, S.; Biernat, J.; Riedel, D.; Mandelkow, E.; Zweckstetter, M. Liquid-liquid phase separation of the microtubulebinding repeats of the Alzheimer-related protein Tau. Nat. Commun. 2017, 8, 275. [CrossRef]

172. Boyko, S.; Qi, X.; Chen, T.H.; Surewicz, K.; Surewicz, W.K. Liquid-liquid phase separation of tau protein: The crucial role of electrostatic interactions. J. Biol. Chem. 2019, 294, 11054-11059. [CrossRef]

173. Lin, Y.; Fichou, Y.; Longhini, A.P.; Llanes, L.C.; Yin, P.; Bazan, G.C.; Kosik, K.S.; Han, S. Electrostatically driven complex coacervation and amyloid aggregation of tau are independent processes with overlapping conditions. J. Mol. Biol. 2021, 433, 166731. [CrossRef] [PubMed]

174. Lester, E.; Ooi, F.K.; Bakkar, N.; Ayers, J.; Woerman, A.L.; Wheeler, J.; Bowser, R.; Carlson, G.A.; Prusiner, S.B.; Parker, R. Tau aggregates are RNA-protein assemblies that mislocalize multiple nuclear speckle components. Neuron 2021, 7. [CrossRef]

175. Yu, H.; Lu, S.; Gasior, K.; Singh, D.; Vazquez-Sanchez, S.; Tapia, O.; Toprani, D.; Beccari, M.S.; Yates, J.R., 3rd; Da Cruz, S.; et al. HSP70 chaperones RNA-free TDP-43 into anisotropic intranuclear liquid spherical shells. Science 2021, 371, eabb4309. [CrossRef] [PubMed]

176. Ercan-Herbst, E.; Ehrig, J.; Schöndorf, D.C.; Behrendt, A.; Klaus, B.; Gomez Ramos, B.; Prat Oriol, N.; Weber, C.; Ehrnhoefer, D.E. A post-translational modification signature defines changes in soluble tau correlating with oligomerization in early stage Alzheimer's disease brain. Acta Neuropathol. Commun. 2019, 7, 192. [CrossRef] [PubMed]

177. Trzeciakiewicz, H.; Tseng, J.H.; Wander, C.M.; Madden, V.; Tripathy, A.; Yuan, C.X.; Cohen, T.J. A Dual Pathogenic Mechanism Links Tau Acetylation to Sporadic Tauopathy. Sci. Rep. 2017, 7, 44102. [CrossRef] [PubMed]

178. Ferreon, J.C.; Jain, A.; Choi, K.J.; Tsoi, P.S.; MacKenzie, K.R.; Jung, S.Y.; Ferreon, A.C. Acetylation Disfavors Tau Phase Separation. Int. J. Mol. Sci. 2018, 19, 1360. [CrossRef] [PubMed]

179. Wegmann, S.; Eftekharzadeh, B.; Tepper, K.; Zoltowska, K.M.; Bennett, R.E.; Dujardin, S.; Laskowski, P.R.; MacKenzie, D.; Kamath, T.; Commins, C.; et al. Tau protein liquid-liquid phase separation can initiate tau aggregation. EMBO J. 2018, 37 , e98049. [CrossRef] 
180. Biernat, J.; Mandelkow, E.M. The development of cell processes induced by tau protein requires phosphorylation of serine 262 and 356 in the repeat domain and is inhibited by phosphorylation in the proline-rich domains. Mol. Biol. Cell. 1999, 10, 727-740. [CrossRef]

181. Patterson, K.R.; Remmers, C.; Fu, Y.; Brooker, S.; Kanaan, N.M.; Vana, L.; Ward, S.; Reyes, J.F.; Philibert, K.; Glucksman, M.J.; et al. Characterization of prefibrillar Tau oligomers in vitro and in Alzheimer disease. J. Biol. Chem. 2011, 286, 23063-23076. [CrossRef]

182. Clavaguera, F.; Duyckaerts, C.; Haik, S. Prion-like properties of Tau assemblies. Curr. Opin. Neurobiol. 2020, 61, 49-57. [CrossRef]

183. Popov, K.I.; Makepeace, K.A.T.; Petrotchenko, E.V.; Dokholyan, N.V.; Borchers, C.H. Insight into the Structure of the "Unstructured" Tau Protein. Structure 2019, 27, 1710-1715.e4. [CrossRef] [PubMed]

184. Falcon, B.; Zivanov, J.; Zhang, W.; Murzin, A.G.; Garringer, H.J.; Vidal, R.; Crowther, R.A.; Newell, K.L.; Ghetti, B.; Goedert, M.; et al. Novel tau filament fold in chronic traumatic encephalopathy encloses hydrophobic molecules. Nature 2019, 568, 420-423. [CrossRef] [PubMed]

185. Falcon, B.; Zhang, W.; Murzin, A.G.; Murshudov, G.; Garringer, H.J.; Vidal, R.; Crowther, R.A.; Ghetti, B.; Scheres, S.H.W.; Goedert, M. Structures of filaments from Pick's disease reveal a novel tau protein fold. Nature 2018, 561, 137-140. [CrossRef]

186. Zhang, W.; Tarutani, A.; Newell, K.L.; Murzin, A.G.; Matsubara, T.; Falcon, B.; Vidal, R.; Garringer, H.J.; Shi, Y.; Ikeuchi, T.; et al. Novel tau filament fold in corticobasal degeneration. Nature 2020, 580, 283-287. [CrossRef] [PubMed]

187. Scheltens, P.; De Strooper, B.; Kivipelto, M.; Holstege, H.; Chételat, G.; Teunissen, C.E.; Cummings, J.; van der Flier, W.M. Alzheimer's disease. Lancet 2021, 397, 1577-1590. [CrossRef]

188. Chen, G.F.; Xu, T.H.; Yan, Y.; Zhou, Y.R.; Jiang, Y.; Melcher, K.; Xu, H.E. Amyloid beta: Structure, biology and structure-based therapeutic development. Acta Pharmacol. Sin. 2017, 38, 1205-1235. [CrossRef]

189. Selkoe, D.J.; Schenk, D. Alzheimer's disease: Molecular understanding predicts amyloid-based therapeutics. Annu. Rev. Pharmacol. Toxicol. 2003, 43, 545-584. [CrossRef]

190. Haass, C.; Lemere, C.A.; Capell, A.; Citron, M.; Seubert, P.; Schenk, D.; Lannfelt, L.; Selkoe, D.J. The Swedish mutation causes early-onset Alzheimer's disease by beta-secretase cleavage within the secretory pathway. Nat. Med. 1995, 1, 1291-1296. [CrossRef]

191. Carter, D.B.; Dunn, E.; Pauley, A.M.; McKinley, D.D.; Fleck, T.J.; Ellerbrook, B.R.; Stratman, N.C.; Zhou, X.; Himes, C.S.; Nye, J.S.; et al. Changes in gamma-secretase activity and specificity caused by the introduction of consensus aspartyl protease active motif in Presenilin 1. Mol. Neurodegener. 2008, 3, 6. [CrossRef]

192. Nunan, J.; Small, D.H. Regulation of APP cleavage by alpha-, beta- and gamma-secretases. FEBS Lett. 2000, 483, 6-10. [CrossRef]

193. Muvva, C.; Murugan, N.A.; Subramanian, V. Assessment of Amyloid Forming Tendency of Peptide Sequences from Amyloid Beta and Tau Proteins Using Force-Field, Semi-Empirical, and Density Functional Theory Calculations. Int. J. Mol. Sci. 2021, 22, 3244. [CrossRef] [PubMed]

194. Eker, F.; Griebenow, K.; Schweitzer-Stenner, R. Abeta(1-28) fragment of the amyloid peptide predominantly adopts a polyproline II conformation in an acidic solution. Biochemistry 2004, 43, 6893-6898. [CrossRef] [PubMed]

195. Murphy, M.P.; LeVine, H., 3rd. Alzheimer's disease and the amyloid-beta peptide. J. Alzheimer's Dis. 2010, 19, 311-323. [CrossRef]

196. Wang, L.; Eom, K.; Kwon, T. Different Aggregation Pathways and Structures for A 40 and A 42 Peptides. Biomolecules 2021, 11, 198. [CrossRef]

197. Sgourakis, N.G.; Yan, Y.; McCallum, S.A.; Wang, C.; Garcia, A.E. The Alzheimer's peptides Abeta40 and 42 adopt distinct conformations in water: A combined MD/NMR study. J. Mol. Biol. 2007, 368, 1448-1457. [CrossRef] [PubMed]

198. Coles, M.; Bicknell, W.; Watson, A.A.; Fairlie, D.P.; Craik, D.J. Solution structure of amyloid beta-peptide(1-40) in a water-micelle environment. Is the membrane-spanning domain where we think it is? Biochemistry 1998, 37, 11064-11077. [CrossRef]

199. Eisenberg, D.S.; Sawaya, M.R. Implications for Alzheimer's disease of an atomic resolution structure of amyloid- $\beta(1-42)$ fibrils. Proc. Natl. Acad. Sci. USA 2016, 113, 9398-9400. [CrossRef]

200. Wildburger, N.C.; Esparza, T.J.; LeDuc, R.D.; Fellers, R.T.; Thomas, P.M.; Cairns, N.J.; Kelleher, N.L.; Bateman, R.J.; Brody, D.L. Diversity of Amyloid-beta Proteoforms in the Alzheimer's Disease Brain. Sci. Rep. 2017, 7, 9520. [CrossRef]

201. Cohen, M.L.; Kim, C.; Haldiman, T.; ElHag, M.; Mehndiratta, P.; Pichet, T.; Lissemore, F.; Shea, M.; Cohen, Y.; Chen, W.; et al. Rapidly progressive Alzheimer's disease features distinct structures of amyloid- $\beta$. Brain 2015, 138, 1009-1022. [CrossRef]

202. Tay, W.M.; Huang, D.; Rosenberry, T.L.; Paravastu, A.K. The Alzheimer's amyloid- $\beta(1-42)$ peptide forms off-pathway oligomers and fibrils that are distinguished structurally by intermolecular organization. J. Mol. Biol. 2013, 425, 2494-2508. [CrossRef]

203. Hayden, E.Y.; Teplow, D.B. Amyloid $\beta$-protein oligomers and Alzheimer's disease. Alzheimers Res. Ther. 2013, 5, 60. [CrossRef]

204. Lau, H.H.C.; Ingelsson, M.; Watts, J.C. The existence of A $\beta$ strains and their potential for driving phenotypic heterogeneity in Alzheimer's disease. Acta Neuropathol. 2020. [CrossRef]

205. Charidimou, A.; Boulouis, G.; Gurol, M.E.; Ayata, C.; Bacskai, B.J.; Frosch, M.P.; Viswanathan, A.; Greenberg, S.M. Emerging concepts in sporadic cerebral amyloid angiopathy. Brain 2017, 140, 1829-1850. [CrossRef] [PubMed]

206. Xu, G.; Fromholt, S.E.; Chakrabarty, P.; Zhu, F.; Liu, X.; Pace, M.C.; Koh, J.; Golde, T.E.; Levites, Y.; Lewis, J.; et al. Diversity in $\mathrm{A} \beta$ deposit morphology and secondary proteome insolubility across models of Alzheimer-type amyloidosis. Acta Neuropathol. Commun. 2020, 8, 43. [CrossRef] [PubMed]

207. Karran, E.; Mercken, M.; De Strooper, B. The amyloid cascade hypothesis for Alzheimer's disease: An appraisal for the development of therapeutics. Nat. Rev. Drug Discov. 2011, 10, 698-712. [CrossRef] [PubMed]

208. Jagust, W. Is amyloid- $\beta$ harmful to the brain? Insights from human imaging studies. Brain 2016, 139, 23-30. [CrossRef] 
209. McAleese, K.E.; Colloby, S.J.; Thomas, A.J.; Al-Sarraj, S.; Ansorge, O.; Neal, J.; Roncaroli, F.; Love, S.; Francis, P.T.; Attems, J. Concomitant neurodegenerative pathologies contribute to the transition from mild cognitive impairment to dementia. Alzheimers Dement. 2021. [CrossRef]

210. Shafiq, M.; Zafar, S.; Younas, N.; Noor, A.; Puig, B.; Altmeppen, H.C.; Schmitz, M.; Matschke, J.; Ferrer, I.; Glatzel, M.; et al. Prion protein oligomers cause neuronal cytoskeletal damage in rapidly progressive Alzheimer's disease. Mol. Neurodegener. 2021, 16, 11. [CrossRef]

211. Crary, J.F.; Trojanowski, J.Q.; Schneider, J.A.; Abisambra, J.F.; Abner, E.L.; Alafuzoff, I.; Arnold, S.E.; Attems, J.; Beach, T.G.; Bigio, E.H.; et al. Primary age-related tauopathy (PART): A common pathology associated with human aging. Acta Neuropathol. 2014, 128, 755-766. [CrossRef]

212. Ciechanover, A.; Kwon, Y.T. Protein Quality Control by Molecular Chaperones in Neurodegeneration. Front. Neurosci. 2017, 11, 185. [CrossRef]

213. Wang, J.; Maldonado, M.A. The ubiquitin-proteasome system and its role in inflammatory and autoimmune diseases. Cell Mol. Immunol. 2006, 3, 255-261. [PubMed]

214. Andre, R.; Tabrizi, S.J. Misfolded PrP and a novel mechanism of proteasome inhibition. Prion 2012, 6, 32-36. [CrossRef] [PubMed]

215. Tai, H.C.; Serrano-Pozo, A.; Hashimoto, T.; Frosch, M.P.; Spires-Jones, T.L.; Hyman, B.T. The synaptic accumulation of hyperphosphorylated tau oligomers in Alzheimer disease is associated with dysfunction of the ubiquitin-proteasome system. Am. J. Pathol. 2012, 181, 1426-1435. [CrossRef] [PubMed]

216. Hegde, A.N.; Upadhya, S.C. Role of ubiquitin-proteasome-mediated proteolysis in nervous system disease. Biochim. Biophys. Acta 2011, 1809, 128-140. [CrossRef] [PubMed]

217. Cuervo, A.M.; Dice, J.F. Traffic. Regulation of lamp2a levels in the lysosomal membrane. Traffic 2000, 1, 570-583. [CrossRef]

218. Bourdenx, M.; Martín-Segura, A.; Scrivo, A.; Rodriguez-Navarro, J.A.; Kaushik, S.; Tasset, I.; Diaz, A.; Storm, N.J.; Xin, Q.; Juste, Y.R.; et al. Chaperone-mediated autophagy prevents collapse of the neuronal metastable proteome. Cell 2021, 184, 2696-2714. [CrossRef]

219. Allen, J.A.; Halverson-Tamboli, R.A.; Rasenick, M.M. Lipid raft microdomains and neurotransmitter signalling. Nat. Rev. Neurosci. 2007, 8, 128-140. [CrossRef]

220. Garofalo, T.; Ferri, A.; Sorice, M.; Azmoon, P.; Grasso, M.; Mattei, V.; Capozzi, A.; Manganelli, V.; Misasi, R. Neuroglobin overexpression plays a pivotal role in neuroprotection through mitochondrial raft-like microdomains in neuroblastoma SK-N-BE2 cells. Mol. Cell. Neurosci. 2018, 88, 167-176. [CrossRef]

221. Area-Gomez, E.; de Groof, A.; Bonilla, E.; Montesinos, J.; Tanji, K.; Boldogh, I.; Pon, L.; Schon, E.A. A key role for MAM in mediating mitochondrial dysfunction in Alzheimer disease. Cell Death Dis. 2018, 19, 335. [CrossRef] [PubMed]

222. Ciarlo, L.; Manganelli, V.; Matarrese, P.; Garofalo, T.; Tinari, A.; Gambardella, L.; Marconi, M.; Grasso, M.; Misasi, R.; Sorice, M.; et al. Raft-like microdomains play a key role in mitochondrial impairment in lymphoid cells from patients with Huntington's disease. J. Lipid Res. 2012, 53, 2057-2068. [CrossRef] [PubMed]

223. Garofalo, T.; Matarrese, P.; Manganelli, V.; Marconi, M.; Tinari, A.; Gambardella, L.; Faggioni, A.; Misasi, R.; Sorice, M.; Malorni, W. Evidence for the involvement of lipid rafts localized at the ER-mitochondria associated membranes in autophagosome formation. Autophagy 2016, 12, 917-935. [CrossRef]

224. Matarrese, P.; Garofalo, T.; Manganelli, V.; Gambardella, L.; Marconi, M.; Grasso, M.; Tinari, A.; Misasi, R.; Malorni, W.; Sorice, M. Evidence for the involvement of GD3 ganglioside in autophagosome formation and maturation. Autophagy 2014, 10, 750-765. [CrossRef] [PubMed]

225. Manganelli, V.; Matarrese, P.; Antonioli, M.; Gambardella, L.; Vescovo, T.; Gretzmeier, C.; Longo, A.; Capozzi, A.; Recalchi, S.; Riitano, G.; et al. Raft-like lipid microdomains drive autophagy initiation via AMBRA1-ERLIN1 molecular association within MAMs. Autophagy 2020. [CrossRef]

226. Cha-Molstad, H.; Sung, K.S.; Hwang, J.; Kim, K.A.; Yu, J.E.; Yoo, Y.D.; Jang, J.M.; Han, D.H.; Molstad, M.; Kim, J.G.; et al. Amino-terminal arginylation targets endoplasmic reticulum chaperone BiP for autophagy through p62 binding. Nat. Cell Biol. 2015, 17, 917-929. [CrossRef]

227. Stephan, J.S.; Fioriti, L.; Lamba, N.; Colnaghi, L.; Karl, K.; Derkatch, I.L.; Kandel, E.R. The CPEB3 Protein Is a Functional Prion that Interacts with the Actin Cytoskeleton. Cell Rep. 2015, 11, 1772-1785. [CrossRef]

228. Mattei, V.; Martellucci, S.; Santilli, F.; Manganelli, V.; Garofalo, T.; Candelise, N.; Caruso, A.; Sorice, M.; Scaccianoce, S.; Misasi, R. Morphine Withdrawal Modifies Prion Protein Expression in Rat Hippocampus. PLoS ONE 2017, 12, e0169571. [CrossRef]

229. Arendt, T.; Bullmann, T. Neuronal plasticity in hibernation and the proposed role of the microtubule-associated protein tau as a "master switch" regulating synaptic gain in neuronal networks. Am. J. Physiol. Regul. Integr. Comp. Physiol. 2013, 305, R478-R489. [CrossRef]

230. Biancalana, M.; Koide, S. Molecular mechanism of Thioflavin-T binding to amyloid fibrils. Biochem. Biophy. Acta 2010, 1804, 1405-1412. [CrossRef]

231. Atarashi, R.; Satoh, K.; Sano, K.; Fuse, T.; Yamaguchi, N.; Ishibashi, D.; Matsubara, T.; Nakagaki, T.; Yamanaka, H.; Shirabe, S.; et al. Ultrasensitive human prion detection in cerebrospinal fluid by real-time quaking-induced conversion. Nat. Med. 2011, 17, 175-178. [CrossRef]

232. Orrú, C.D.; Groveman, B.R.; Hughson, A.G.; Zanusso, G.; Coulthart, M.B.; Caughey, B. Rapid and sensitive RT-QuIC detection of human Creutzfeldt-Jakob disease using cerebrospinal fluid. mBio 2015, 6, e02451-14. [CrossRef] 
233. Fairfoul, G.; McGuire, L.I.; Pal, S.; Ironside, J.W.; Neumann, J.; Christie, S.; Joachim, C.; Esiri, M.; Evetts, S.G.; Rolinski, M.; et al. Alpha-synuclein RT-QuIC in the CSF of patients with alpha-synucleinopathies. Ann. Clin. Transl. Neurol. 2016, 3, 812-818. [CrossRef] [PubMed]

234. Rossi, M.; Candelise, N.; Baiardi, S.; Capellari, S.; Giannini, G.; Orrù, C.D.; Antelmi, E.; Mammana, A.; Hughson, A.G.; Calandra-Buonaura, G.; et al. Ultrasensitive RT-QuIC assay with high sensitivity and specificity for Lewy body-associated synucleinopathies. Acta Neuropathol. 2020, 140, 49-62. [CrossRef]

235. Saijo, E.; Ghetti, B.; Zanusso, G.; Oblak, A.; Furman, J.L.; Diamond, M.I.; Kraus, A.; Caughey, B. Ultrasensitive and selective detection of 3-repeat tau seeding activity in Pick disease brain and cerebrospinal fluid. Acta Neuropathol. 2017, 133, 751-765. [CrossRef]

236. Saijo, E.; Metrick, M.A., 2nd; Koga, S.; Parchi, P.; Litvan, I.; Spina, S.; Boxer, A.; Rojas, J.C.; Galasko, D.; Kraus, A.; et al. 4-Repeat tau seeds and templating subtypes as brain and CSF biomarkers of frontotemporal lobar degeneration. Acta Neuropathol. 2020, 139, 63-77. [CrossRef] [PubMed]

237. Kraus, A.; Saijo, E.; Metrick, M.A., 2nd; Newell, K.; Sigurdson, C.J.; Zanusso, G.; Ghetti, B.; Caughey, B. Seeding selectivity and ultrasensitive detection of tau aggregate conformers of Alzheimer disease. Acta Neuropathol. 2019, 137, 585-598. [CrossRef]

238. Scialò, C.; Tran, T.H.; Salzano, G.; Novi, G.; Caponnetto, C.; Chiò, A.; Calvo, A.; Canosa, A.; Moda, F.; Caroppo, P.; et al. TDP-43 real-time quaking induced conversion reaction optimization and detection of seeding activity in CSF of amyotrophic lateral sclerosis and frontotemporal dementia patients. Brain Commun. 2020, 2, fcaa142. [CrossRef] [PubMed]

239. Orrú, C.D.; Groveman, B.R.; Raymond, L.D.; Hughson, A.G.; Nonno, R.; Zou, W.; Ghetti, B.; Gambetti, P.; Caughey, B. Bank Vole Prion Protein As an Apparently Universal Substrate for RT-QuIC-Based Detection and Discrimination of Prion Strains. PLoS Pathog. 2015, 11, e1004983. [CrossRef]

240. Shahnawaz, M.; Mukherjee, A.; Pritzkow, S.; Mendez, N.; Rabadia, P.; Liu, X.; Hu, B.; Schmeichel, A.; Singer, W.; Wu, G.; et al Discriminating alpha-synuclein strains in Parkinson's disease and multiple system atrophy. Nature 2020, 578, 273-277. [CrossRef]

241. Candelise, N.; Schmitz, M.; Llorens, F.; Villar-Piqué, A.; Cramm, M.; Thom, T.; da Silva Correia, S.M.; da Cunha, J.E.G.; Möbius, W.; Outeiro, T.F.; et al. Seeding variability of different alpha synuclein strains in synucleinopathies. Ann. Neurol. 2019, 85, 691-703. [CrossRef]

242. Hermann, P.; Appleby, B.; Brandel, J.P.; Caughey, B.; Collins, S.; Geschwind, M.D.; Green, A.; Haik, S.; Kovacs, G.G.; Ladogana, A.; et al. Biomarkers and diagnostic guidelines for sporadic Creutzfeldt-Jakob disease. Lancet Neurol. 2021, 20, 235-246. [CrossRef]

243. Llorens, F.; Villar-Piqué, A.; Schmitz, M.; Diaz-Lucena, D.; Wohlhage, M.; Hermann, P.; Goebel, S.; Schmidt, I.; Glatzel, M.; Hauw, J.J.; et al. Plasma total prion protein as a potential biomarker for neurodegenerative dementia: Diagnostic accuracy in the spectrum of prion diseases. Neuropathol. Appl. Neurobiol. 2020, 46, 240-254. [CrossRef] [PubMed]

244. Palmqvist, S.; Janelidze, S.; Quiroz, Y.T.; Zetterberg, H.; Lopera, F.; Stomrud, E.; Su, Y.; Chen, Y.; Serrano, G.E.; Leuzy, A.; et al. Discriminative Accuracy of Plasma Phospho-tau217 for Alzheimer Disease vs Other Neurodegenerative Disorders. JAMA 2020, 324, 772-781. [CrossRef] [PubMed]

245. Uddin, M.S.; Kabir, M.T.; Niaz, K.; Jeandet, P.; Clément, C.; Mathew, B.; Rauf, A.; Rengasamy, K.R.R.; Sobarzo-Sánchez, E.; Ashraf, G.M.; et al. Molecular Insight into the Therapeutic Promise of Flavonoids against Alzheimer's Disease. Molecules 2020, $25,1267$. [CrossRef] [PubMed]

246. Schmitz, M.; Candelise, N.; Kanata, E.; Llorens, F.; Thüne, K.; Villar-Piqué, A.; da Silva Correia, S.M.; Dafou, D.; Sklaviadis, T.; Appelhans, D.; et al. Validation of Poly(Propylene Imine) Glycodendrimers Towards Their Anti-prion Conversion Efficiency. Mol. Neurobiol. 2020, 57, 1863-1874. [CrossRef]

247. Peña-Díaz, S.; Pujols, J.; Pinheiro, F.; Santos, J.; Pallarés, I.; Navarro, S.; Conde-Gimenez, M.; García, J.; Salvatella, X.; Dalfó, E.; et al. Inhibition of alpha-Synuclein Aggregation and Mature Fibril Disassembling With a Minimalistic Compound, ZPDm. Front. Bioeng. Biotechnol. 2020, 8, 588947. [CrossRef]

248. Aldewachi, H.; Al-Zidan, R.N.; Conner, M.T.; Salman, M.M. High-Throughput Screening Platforms in the Discovery of Novel Drugs for Neurodegenerative Diseases. Bioengineering 2021, 8, 30. [CrossRef]

249. Salman, M.M.; Al-Obaidi, Z.; Kitchen, P.; Loreto, A.; Bill, R.M.; Wade-Martins, R. Advances in Applying Computer-Aided Drug Design for Neurodegenerative Diseases. Int. J. Mol. Sci. 2021, 22, 4688. [CrossRef]

250. Brunden, K.R.; Ballatore, C.; Crowe, A.; Smith, A.B., III; Lee, V.M.Y.; Trojanowski, J.Q. Tau-directed drug discovery for Alzheimer's disease and related tauopathies: A focus on tau assembly inhibitors. Exp. Neurol. 2010, 223, 304-310. [CrossRef]

251. Khan, N.I.; Song, E. Lab-on-a-Chip Systems for Aptamer-Based Biosensing. Micromachines 2020, 11, 220. [CrossRef] [PubMed] 